
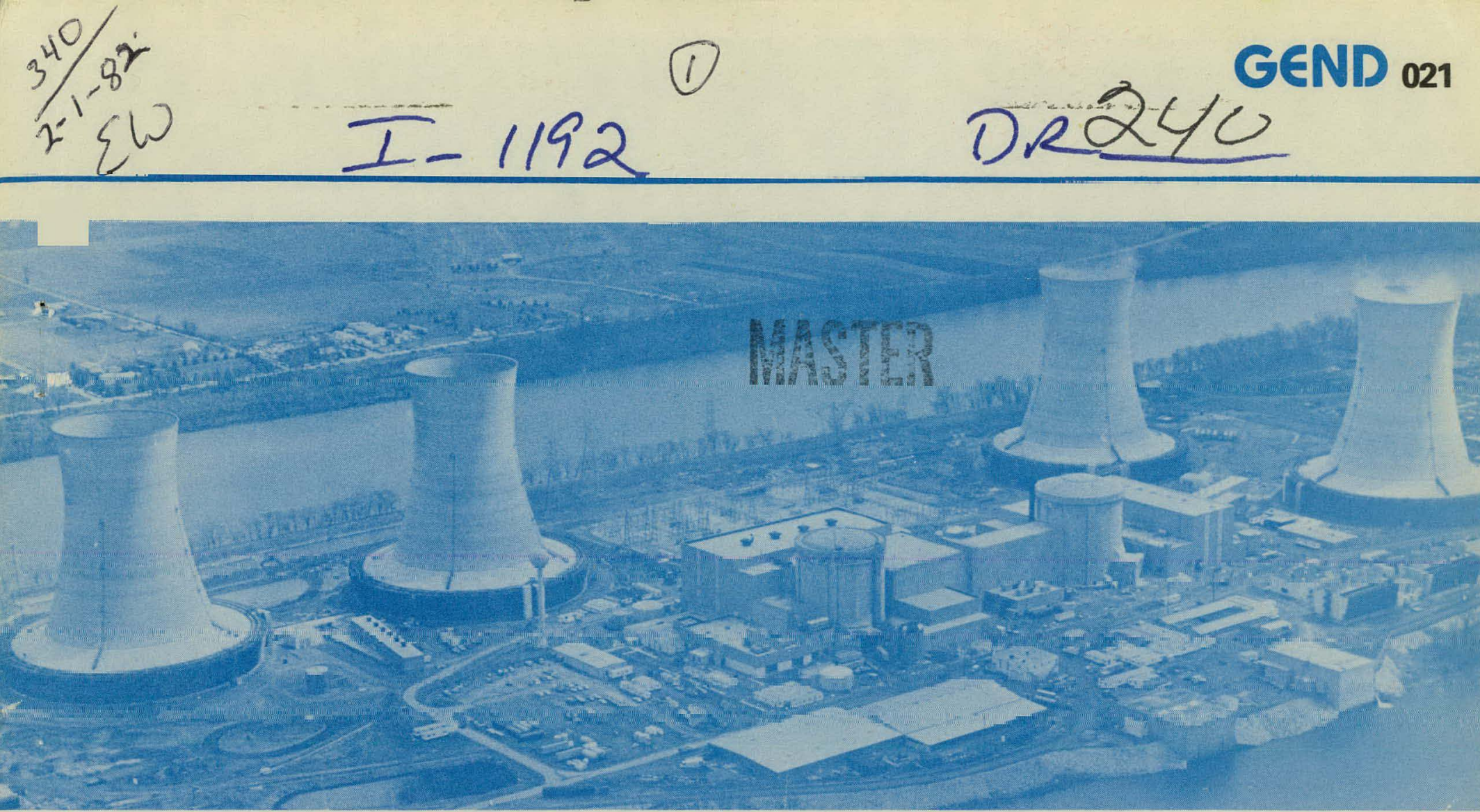

\title{
GEND
}

General Public Utilities - Electric Power Research Institute - U.S. Nuclear Regulatory Commission - U.S. Department of Energy

\section{Controlled Air Incinerator Conceptual Design Study}

\section{Bechtel Northern Corporation}

January 1982

\section{Prepared for the}

U.S. Department of Energy

Three Mile Island Operations Office

Under DOE Contract No. DE-AC07-76ID01570 


\section{DISCLAIMER}

This report was prepared as an account of work sponsored by an agency of the United States Government. Neither the United States Government nor any agency Thereof, nor any of their employees, makes any warranty, express or implied, or assumes any legal liability or responsibility for the accuracy, completeness, or usefulness of any information, apparatus, product, or process disclosed, or represents that its use would not infringe privately owned rights. Reference herein to any specific commercial product, process, or service by trade name, trademark, manufacturer, or otherwise does not necessarily constitute or imply its endorsement, recommendation, or favoring by the United States Government or any agency thereof. The views and opinions of authors expressed herein do not necessarily state or reflect those of the United States Government or any agency thereof. 


\section{DISCLAIMER}

Portions of this document may be illegible in electronic image products. Images are produced from the best available original document. 
Printed in the United States of America

Available from

National Technical Information Service

U.S. Department of Commerce

5285 Port Royal Road

Springfield, VA 22161

NTIS Price Codes: Printed Copy A04

Microfiche A01

\section{DISCLAIMER}

This book was prepared as an account of work sponsored by an agency of the United States Government. Neither the United States Government nor any agency thereof, nor any of their employees, makes any warranty, express or implied, or assumes any legal liability or responsibility for the accuracy, completeness, or usefulness of any information, apparatus, product or process disclosed, or represents that its use would not infringe privately owned rights. References herein to any specific commercial product, process, or service by trade name, trademark, manufacturer, or otherwise, does not necessarily constitute or imply its endorsement, recommendation, or favoring by the United States Government or any agency thereof. The views and opinions of authors expressed herein do not necessarily state or reflect those of the United States Government or any agency thereof. 
GEND--021

GEND-021

DE82 010039

\title{
CONTROLLED AIR INCINERATOR CONCEPTUAL DESIGN STUDY
}

\author{
Bechtel Northern Corporation
}

January 1982

\section{Published on Behalf of the GEND Group \\ by \\ EG\&G Idaho, Inc. \\ Idaho Falls, Idaho 83415}

Prepared for the

U.S. Department of Energy

Three Mile Island Operations Office

Under DOE Contract No. DE-AC07-78ID01570 


\section{ABSTRACT}

This report presents a conceptual design study for a controlled air incinerator facility for incineration of low level combustible waste at Three Mile Island Unit 2 (TMI-2). The facility design is based on the use of a Helix* Process Systems controlled air incinerator. Cost estimates and associated engineering, procurement, and construction schedules are also provided. The cost estimates and schedules are presented for two incinerator facility designs, one with provisions for waste ash solidification, the other with provisions for packaging the waste ash for transport to an undefined location. 
TMI-2 WASTE STREAM CHARACTERIZATION

Waste Input Volume

Generation Rates

Waste Form

Isotopic Consistency

INCINERATOR FACILITY DESIGN

Location

General Layout

Building

Waste Receiving and Preparation

Incinerator System

Heating, Ventilating, and Air-Conditioning (HVAC) System

Compressed Air System

Demineralized Water System

Closed Cooling Water System

Fue 10 il System

Blowdown System

Fire Protection Syst.em

Radiation Monitoring .

Shielding 
CONTENTS (Continued)

Electrical Power

Lighting and Communications

Solidification

Ash Handling (Without Solidification)

Change Area and Office

EXPERIENCE FROM EXISTING CONTROLLED AIR INCINERATORS

Los Alamos Scientific Laboratory (LASL)

Bruce Nuclear Power Development (BNPD)

Savannah River Laboratory (SRL)

Westinghouse

DESIGN ASSESSMENTS

Effect of Waste Composition On Volume Reduction

Effect of Environmental Releases On Incinerator Building Exhaust Filtration

Effect of Alternate Isotopic Content of Incinerator Feed On Building HVAC and Shielding

State

Nuclear Regulatory Commission (NRC)

Environmental Protection Agency (EPA) 
CONTENTS (Continued)

QUALITY ASSURANCE REQUIREMENTS

SCHEDULE

51

COST

54

Cost Summary and Assumptions

Major Cost Uncertainties

SUMMARY

Potential Problems

Waste Form

Waste Type

Incinerator System

Recommendations

REFERENCES

68

APPENDIX A - INCINERATOR FACILITY CRITERIA

APPENDIX B - GPU COST INFORMATION (From Letter TMI-II-R-4300-81-181, dated June 26,1981 ) 
CONTENTS (Continued)

\section{LIST OF FIGURES}

Figure 1 Recovery Facilities Plan. 13

Figure 2 General Arrangement Incinerator (With . 15 Solidification)

Figure 3 General Arrangement Incinerator (Without 16 Solidification)

Figure 4 HVAC Schematic 21

Figure 5 Compressed Air System Schematic ‥ $\quad 23$

Figure 6 Demineralized Water System Schematic 24

Figure 7 Closed Cooling Water System Schematic 26

Figure 8 Fuel 0 il System Schematic 27

$\begin{array}{lll}\text { Figure } 9 \text { Blowdown System Schematic } & 29\end{array}$

Figure 10 Fire Protection Schematic 30

Figure 11 Symbols and Identification Legend . 31

Figure 12 EPC Schedule 52 
CONTENTS (Continued)

\section{LIST OF TABLES}

Table 1 Compacted Waste Form Prior to Start of Incinerator 6 Operations

Table 2 Noncompacted Waste Form After Start of Incinerator 7 Operations

Table 3 Noncompacted Waste Isotopic Consistency 10

$\begin{array}{lll}\text { Table } 4 & \text { Equipment Codes } & 50\end{array}$

Table 5 Controlled Air Incinerator With Solidification 57 Project Cost Percentages

Table 6 Controlled Air Incinerator Without Solidification 58 Project Cost Percentages

Table 7 Solidification - Start Engineering 11-1-81 59

Table 8 Non-Solidification - Start Engineering 11-1-81 60

Table 9 Solidification - Start Engineering 4-1-82 61

Table 10 Non-Solidification - Start Engineering 4-1-82 62 


\title{
CONTROLLED AIR INCINERATOR
}

CONCEPTUAL DESIGN STUDY

\author{
INTRODUCTION
}

The function of a proposed controlled air incinerator (CAI) at TMI-2 is twofold: (a) to demonstrate the operation of a radwaste incinerator at a commercial nuclear facility, and (b) to reduce the volume of combustible low-level radwaste which must be stored and eventually shipped off site. The purpose of this report is to provide a cost estimate and project schedule in sufficient detail to provide General Public Utilities (GPU) and the U.S. Department of Energy (DOE) with a reliable basis for considering a shared radwaste incineration project.

This report provides a conceptual design for a low-level beta-gamma radwaste incinerator facility at TMI-2, using a Helix Process Systems ${ }^{a}$ controlled air incinerator. The report includes estimated TMI-2 waste stream data; basic incinerator facility criteria, and a conceptual design for the incinerator facility and its support systems. Costs, schedules, and licensing requirements for the incinerator facility are also given.

The design of the incinerator facility presents two different facility options, one with provisions for waste ash solidification, the other with provisions for packaging the waste ash for transport to an undefined location.

Two options are provided to account for: (a) individual facility solidification processing, or (b) transport of ash elsewhere for solidification or other means of stabilization, such as high integrity containers (HIC).

No system design optimization was performed during this study. The design presented herein was developed in only enough detail to obtain an estimate of the costs associated with an incinerator facility. The uncertainty range associated with the cost estimate presented in this report is 25 percent.

a. Helix Process Systems has recently been acquired by Koch Industries, Inc., and is now known as Koch Process Systems, Inc. 
Use of the Helix Process Systems CAI as a design basis was a matter of study scope definition, and as such, is considered representative of the Los Alamos Scientific Laboratory (LASL) CAI, which the DOE wishes to commercialize. ${ }^{2}$

a. Although the design presented in this report is based on the use of a Helix Process Systems CAI system, Bechtel Northern Corporation does not necessarily support the use of a Helix system at TMI-2. 
The characterization of waste at TMI-2 given below is for all low-level combustible waste expected to be generated from normal and containment decontamination operations.

\section{Waste Input Volume}

Based on information contained in the TMI-2 Radwaste Storage Facilities Task Group Report ${ }^{1}$, approximately 17,560 drums of compacted waste (three to one compaction), including approximately 160 drums of glass, will be generated before the completion of TMI-2 containment decontamination. In addition, approximately $1,000 \mathrm{ft}^{3}$ of condensate polisher resins and $51,500 \mathrm{ft}^{3}$ of waste oil have been or will be generated from normal plant operations. Assuming incinerator facility availability during the early phases of manual decontamination of containment elevations $305^{\prime}-0^{\prime \prime}$ and $347^{\prime}-6^{\prime \prime}$, and assuming that the glass is kept separate from the combustible waste at the point of generation (via administrative controls), it is estimated that the volume of combustible waste from TMI-2 will total approximately $378,500 \mathrm{ft}^{3}$. This quantity represents the total volume of waste in its form as feed to the incinerator. A facility availability date later than during manual decontamination of containment elevations $305^{\prime}-0^{\prime \prime}$ and $347^{\prime}-6^{\prime \prime}$ will result in more waste being compacted prior to this date, thus lowering the total volume (and increasing the density) of the waste fed to the incinerator.

\section{Generation Rates}

Prior to the availability of the incinerator facility, all waste is expected to be compacted. The total volume of waste generated before the start of incineration, after partial (67 percent) decompaction, has been estimated at $114,653 \mathrm{ft}^{3}$. The maximum generation rate during this period is approximately $2,540 \mathrm{ft}^{3}$ per weck and occurs during gross decontamination of elevations $305^{\prime}-0^{\prime \prime}$ and $347^{\prime}-6^{\prime \prime}$. 
Once the incinerator becomes operational, only noncompacted waste is expected to be brought into the incinerator facility. From the start of incinerator operations until the completion of containment decontamination, approximately $211,320 \mathrm{ft}^{3}$ of waste, in the form of feed to the incinerator, is expected to be generated. The maximum generation rate during the period is $3,275 \mathrm{ft}^{3}$ per week and occurs during manual decontamination of containment elevation $282^{\prime}-6^{\prime \prime}$; this generation rate was used as the basis for the conceptual design presented in this report. A change in the waste generation rates at TMI-2, however, will have little impact on the design of the incinerator facility. Facility storage requirements would not be affected significantly by a change in generation rate since most waste will be stored elsewhere prior to incineration. Furthermore, the 350 pound per hour unit selected should be able to incinerate more than the maximum projected generation per week.

\section{Waste Form}

Combustible waste generated at TMI-2 is expected to come from two sources: waste generated from normal operations and waste generated from containment decontamination. Waste generated from normal operations is based on data provided by General Public Utilities $(G P U)^{2}$. These data represent a sampling of wastes generated during TMI-2 auxiliary building decontamination (i.e., by volume, 30 percent paper, 60 percent plastic, 5 percent cloth, 2 percent rubber, and 3 percent glass). It is estimated that 10 percent of the total auxiliary building decontamination waste volume is PVC material; the materials considered to be PVC consisted of gloves, booties, and reinforced sheeting $^{\mathrm{a}}$. It is assumed that the glass included in the normal TMI-2 waste total will be separated at the point of generation and disposed of with other noncombustibles, such as metal and masonry. Waste generated from containment decontamination operations is based on estimates given in the TMI- 2 Radwaste Storage Facilities Task Group Report (see Reference 1), and in the "Three Mile Island-Unit 2 Planning Study for Containment Entry and Decontamination,"

a. Approximately one-third of the plastic waste from the auxiliary building decontamination consisted of gloves, booties, and sheeting. One-half of the plastic gloves, booties, and sheeting was assumed to be PVC $\left(\frac{1}{2} \times 33 \%\right.$ $x 60 \%$ plastic $=10 \%$ of total waste PVC). 
dated July 2, 1979. ${ }^{3}$ These containment decontamination wastes are expected to be composed of (by volume) 14.4 percent paper, 14.6 percent rags, 36.8 percent plastic, 26.1 percent clothing, 1.4 percent rubber, 0.2 percent wood, and 6.5 percent PVC.

Wastes generated prior to the availability of the incinerator facility will be prepared for incineration by decompacting the stored drums. The combined form of normal and containment decontamination waste, following decompaction, is expected to be as shown in Table 1. 
TABLE 1. COMPACTED WASTE FORM PRIOR TO START OF INCINERATOR OPERATIONS

(Normal and Containment Decontamination Wastes)

\begin{tabular}{|c|c|c|c|c|}
\hline & Vol: (\%) & $\mathrm{ft}^{3}$ & Weight (\%) & Heating Value (Btu/lb) \\
\hline Paper & 23.2 & 26,622 & 18.5 & 7,530 \\
\hline Rags & 6.8 & 7,806 & 8.7 & 7,200 \\
\hline Plastic & 44.7 & 51,244 & 43.1 & 19,950 \\
\hline Clothing & 14.9 & 17,126 & 19.1 & 7,200 \\
\hline Rubber & 1.8 & 2,014 & 2.3 & 15,180 \\
\hline Wood & 0.1 & 51 & 0.1 & 8,500 \\
\hline PVC & 8.5 & 9,790 & 8.2 & 9,750 \\
\hline $\begin{array}{l}\text { Total } \\
\text { Average }\end{array}$ & $\begin{array}{c}100 \\
y=18.2\end{array}$ & $t^{3}{ }^{114,653}$ as $f$ & $\begin{array}{l}100 \\
\text { to the inc }\end{array}$ & nerator) 13,150 (avg.) \\
\hline
\end{tabular}

The combined form of normal operations and containment decontamination wastes generated after the start of incinerator operations is given in Table 2. 
TABLE 2. NONCOMPACTED WASTE FORM AFTER START OF

INCINERATOR OPERATIONS

(Normal and Containment Decontamination Wastes)

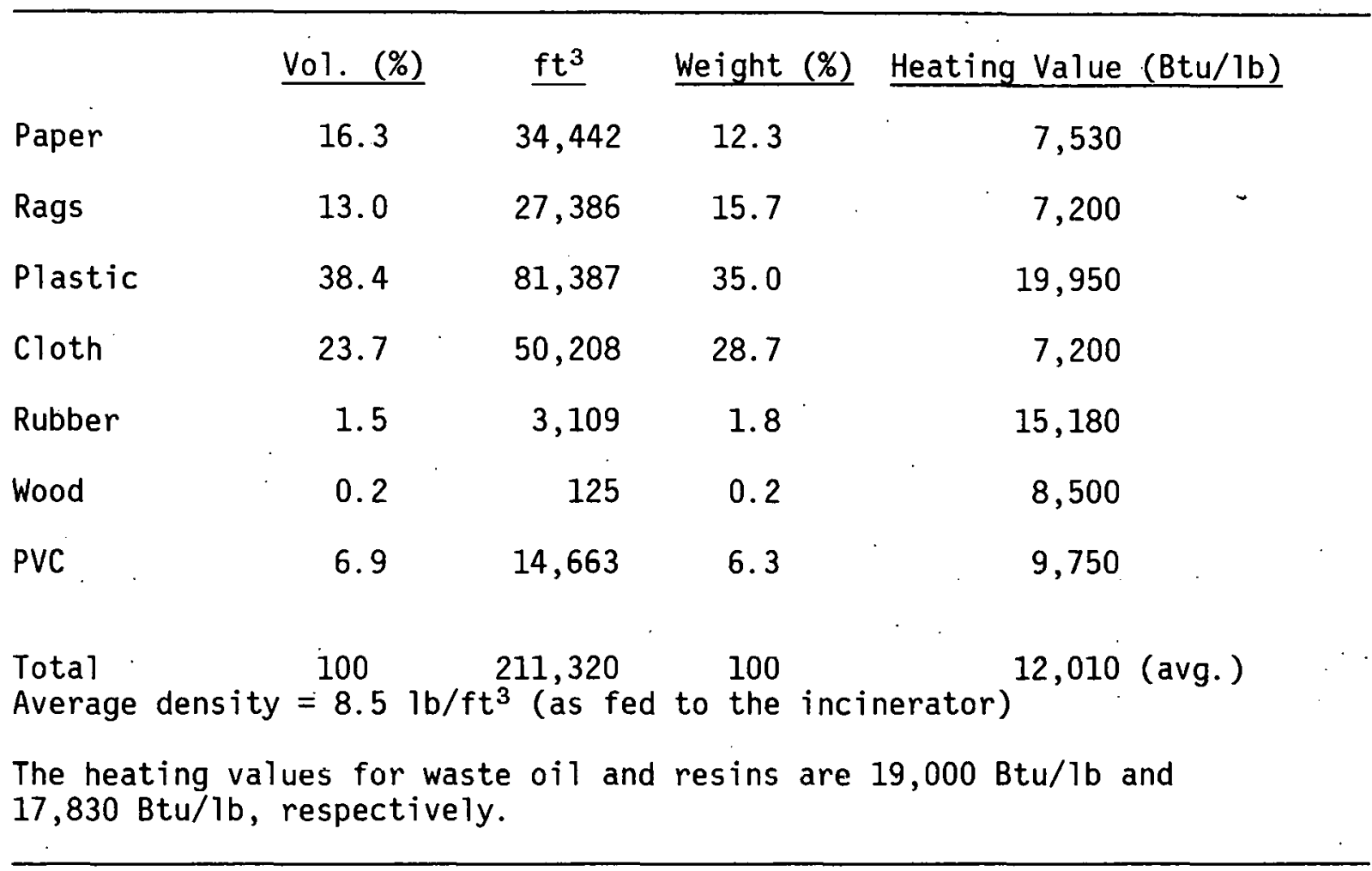

The waste volume percentages are slightly different prior to and after the start of incineration due to different generation rates between normal and containment decontamination wastes at those times. The average density before the availability of the incinerator facility is greater due to compaction of the waste prior to this date.

When PVC and rubber are incinerated, hydrochloric acid and sulfuric acid gases are formed, which must be neutralized in the off-gas scrubbing system by caustic addition. The addition of caustic and the resultant formation of neutralization salts caused from burning PVC and rubber necessitates a blowdown from the wet-off gas scrub solution considered for this sludy. In order to control impact and costs from scrub solution blowdown that would have to be processed, the design of the incinerator. facility for this study 
has only considered a blowdown quantity which can be solidified with cement in two $50 \mathrm{ft}^{3}$ liners per week (approximately $375 \mathrm{gallons).} \mathrm{The} \mathrm{two} 50 \mathrm{ft}^{3}$ liners per week limitation on blowdown was judged as an amount that would not significantly impact normal operations. (Injection of blowdown directly into the incinerator was not considered since this operation is not currently available with the Helix incinerator.) To limit the blowdown quantity to this amount, the PVC and rubber content of the waste fed to the incinerator will have to be restricted to approximately 0.5 percent by weight. ${ }^{a}$ By restricting PVC and rubber in the waste feed, the total volumes of waste given in Tables 1 and 2 are reduced by $11,804 \mathrm{ft}^{3}$ and $17,772 \mathrm{ft}^{3}$, respectively. The average density and heating value of the waste are not significantly - affected by the removal of PVC and rubber from the waste feed.

\section{Isotopic Consistency}

The isotopic content of the incinerator feed was calculated by estimating the total amount of radioactivity that will be contained in combustible trash resulting from the decontamination of elevations $305^{\prime}-0^{\prime \prime}$ and $347^{\prime}-6^{\prime \prime}$. A preliminary analysis of containment entry data indicated that the contamination contained on the walls and floors of the two elevations is:

\begin{tabular}{lr} 
Isotope & $\mathrm{Cj}$ \\
\hline $\mathrm{Cs}-137$ & 184 \\
$\mathrm{Ba}-137 \mathrm{~m}$ & 172 \\
$\mathrm{Cs}-134$ & 23 \\
$\mathrm{~S}-90$ & 8 \\
$\mathrm{Y}-90$ & 8
\end{tabular}

a. This PVC and rubber restriction is based on information provided by the incinerator vendor, and is the subject of recommendations stated later in this report. (See Recommendations, page 65.) 
It was assumed that an overall decontamination factor (DF) of two would be achieved by gross decontamination, resulting in 50 percent of the above activity being washed to the containment sump for removal via the Submerged Demineralizer System (SDS). The remaining activity on the walls and floors was assumed to be removed during manual decontamination. Manual decontamination was assumed to have an overall DF of two, resulting in one-half of the remaining activity, being removed by chemical solutions, wet vacuums, etc. The remaining activity, representing 25 percent of the original activity on the floors and walls of elevations $305^{\prime}-0^{\prime \prime}$ and $347^{\prime}-6^{\prime \prime}$, is assumed to be deposited on combustible trash. The isotope quantities removed on combustible trash are:

\begin{tabular}{lr} 
Isotope & $\mathrm{Ci}$ \\
\cline { 2 - 2 } $\mathrm{Cs}-137$ & 46 \\
$\mathrm{Ba}-137 \mathrm{~m}$ & 43 \\
$\mathrm{Cs}-134$ & 6 \\
$\mathrm{~S}-90$ & 2 \\
$\mathrm{Y}-90$ & $2:$
\end{tabular}

For this study, it has been assumed that the activity is removed in approximately 2,700 55-gallon drums of compacted trash. This encompasses the expected combustible waste generated during the gross decontamination of

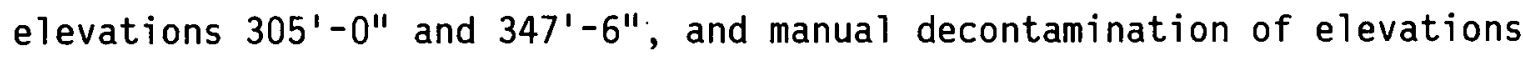
$305^{\prime}-0^{\prime \prime}$ and $347^{\prime}-6^{\prime \prime}$ prior to operation of the incinerator. A compaction factor of three was used to determine the noncompacted volume of the 2,700 drums of trash. This resulted in an incinerator feed isotopic concentration of $0.059 \mu \mathrm{Ci} / \mathrm{cm}^{3}$, distributed as shown in Table 3 . 


$\begin{array}{ll}\text { Isotope } & \mu \mathrm{Ci} / \mathrm{cm}^{3} \\ \mathrm{Cs}-137 & 0.0272 \\ \mathrm{Ba}-137 \mathrm{~m} & 0.0255 \\ \mathrm{Cs}-134 & 0.0034 \\ \mathrm{Sr}-90 & 0.00119 \\ \mathrm{Y}-9 & 0.00119\end{array}$

NOTE: Turbine lube oil contamination is nil, and condensate polisher resins contain $0.0688 \mu \mathrm{Ci} / \mathrm{cm}^{3}$ of $\mathrm{Cs}-137$.

To verify the validity of a design basis value of $0.059 \mu \mathrm{Ci} / \mathrm{cm}^{3}$, the incinerator feed isotopic concentration was compared with the isotopic concentration of trash generated during the TMI-2 auxiliary and fuel handling buildings decontamination and a pressurized water reactor (PWR) steam generator repair effort.

During decontamination of the TMI-2 auxiliary and fuel handing buildings, 1,623 55-gallon drums containing 28 curies were generated and shipped. A compaction factor of five was used for this trash, which equates to a volume of noncompacted trash contained in the 1,623 drums of $1.69 \times 10^{9} \mathrm{~cm}^{3}$. This yields a noncompacted trash isotopic concentration of $0.017 \mu \mathrm{Ci} / \mathrm{cm}^{3}$, which is slightly less than one-third of the calculated feed concentration. Should the incinerator feed concentration be based on a compaction factor of five, as was done for the auxiliary building and fuel handling building waste, the feed isotopic concentration would be $0.035 \mu \mathrm{Ci} / \mathrm{cm}^{3}$, which is only about twice the concentration of that generated in the decontamination of the auxiliary and fuel handling buildings. ${ }^{a}$

a. The isotopic concentration is reduced from $0.059 \mu \mathrm{Ci} / \mathrm{cm}^{3}$ due to a greater quantity of combustible material being contained in each drum with a compaction factor of five. 
The PWR steam generator repair effort resulted in the generation of 57,790 $\mathrm{ft}^{3}$ of trash containing $63.6 \mathrm{Ci}$. This yields a concentration of 0.039 $\mu \mathrm{Ci} / \mathrm{cm}^{3}$, which correlates well with the calculated incinerator feed isotopic concentration.

Because of the reasonable correlation of the calculated feed isotopic concentration with available data, for the purpose of this study, the calculated concentration of $0.059 \mu \mathrm{Ci} / \mathrm{cm}^{3}$ is used as the basis for all other nuclear analyses. The use of $0.059 \mu \mathrm{Ci} / \mathrm{cm}^{3}$, as opposed to the somewhat lower values of 0.035 and 0.039 , is not expected to significantly affect the results of this study. 


\section{INCINERATOR FACILITY DESIGN}

Following is a description of the incinerator facility designs developed for this study. Appendix A provides the criteria used as the basis for these designs.

\section{Location}

The incinerator facility will be housed in a building located south of and adjacent to the south dike, as shown in Figure 1.

Several locations were considered for the incinerator, including the Unit 2 model shop located at the north end of the Unit 2 fuel handling building, at elevation 305'-0". Although installation of an incinerator system in the model shop may be possible, given the relatively small volume of this room, it was determined that operation and maintenance would be difficult, and that "As Low As Is Reasonably Achievable" (ALARA) considerations would be compromised. Moreover, requirements for waste storage and ash solidification or packaging would be difficult to satisfy, and the use of this area would not necessarily preclude the need for some independent support systems. The loads on the existing cooling water and HVAC systems would be substantial, and would probably require that these systems be upgraded or supplemented to accommodate incinerator operation. Finally, since the model shop is a high traffic area, and incinerator feed and ash handling operations would probably require restricted use of the nearby Unit 1 and Unit 2 refueling bay, it was determined that the model shop was not appropriate. New building locations, closer to the main power block than the chosen location, were also investigated. For example, the proposed Decontamination Demonstration. Facility location west of the evaporator building was determined to be unsatisfactory, since the larger size of the incinerator facility would have to be built over safety-related piping and the fire main would have to be relocated. The area east of the Interim Solid Waste Staging Facility (ISWSF) was rejected due to excessive backfill that would be necessary to construct the facility, and the 


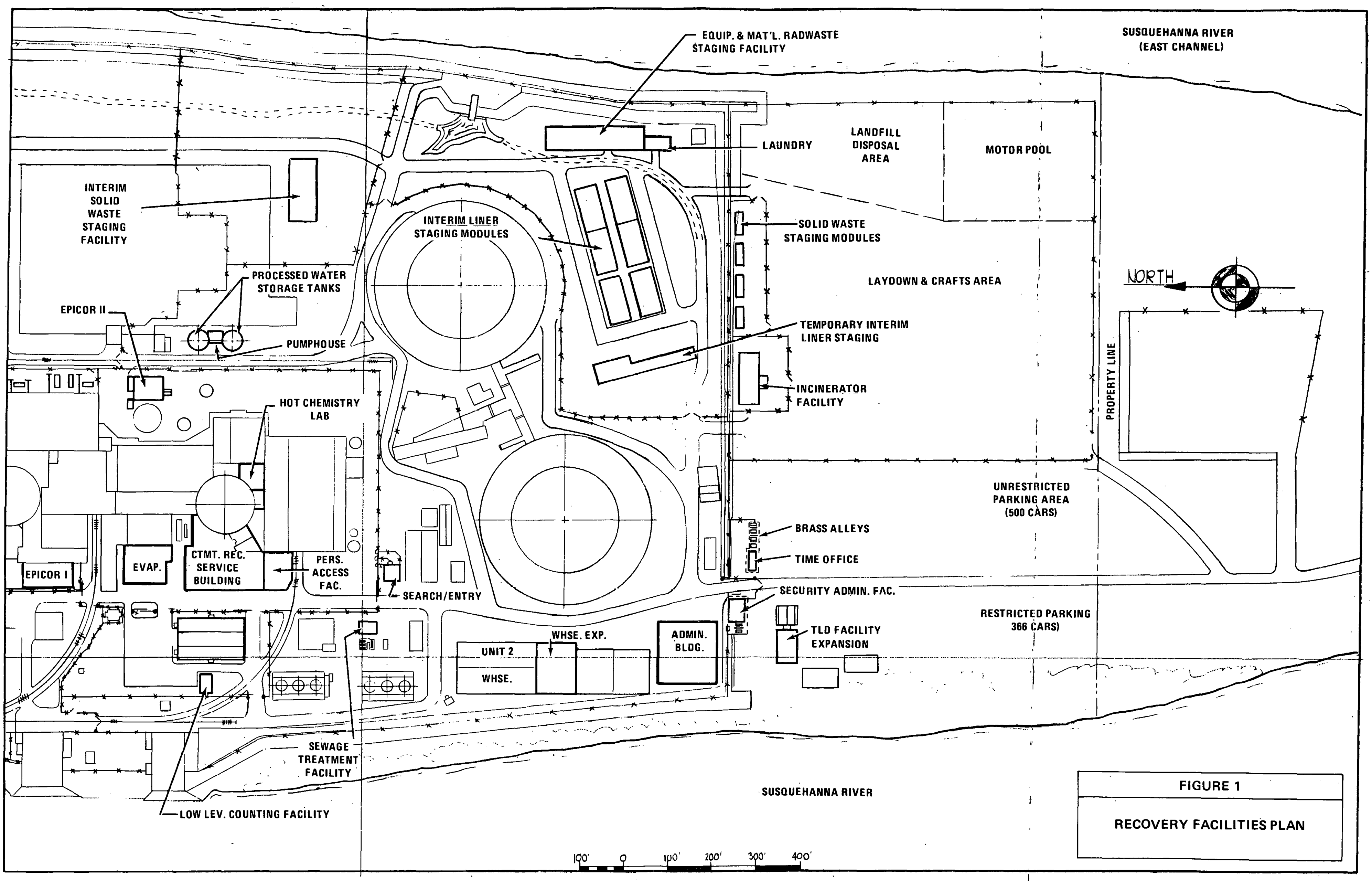


possibility of increased shielding requirements. Depending on where incinerator waste feed is staged, however, an evaluation should be performed during detailed engineering to reevaluate the possibility of locating the incinerator facility east of the ISWSF.

\section{General Layout}

The layout of the facility will encompass a waste receiving area, an incineration process area, an ash handling area, and an area for all necessary support services required for incinerator operation and maintenance, taking into account ALARA considerations. Support services equipment located adjacent to the building include a fuel oil storage tank, a demineralized water storage tank, a closed cooling water heat exchanger, an air-cooled condensing unit, and a power transformer. Since two facility designs are considered in this study, a different layout is provided for each option. The layout with an area for ash solidification is shown in Figure 2 . The layout with provisions to load ash into containers for transport to another location is shown in Figure 3.

\section{Building}

The building housing the incinerator facility (refer to Figures 2 and 3 ) will consist of a pre-engineered rigid frame metal building spanning 50 feet in width, 140 feet in length, and with an eaves height of 19 feet. The building will be designed for the basic wind and snow loads specified in the TMI Civil Structural Design Criteria, ${ }^{4}$ and will be designed for the minimum seismic loads as determined by the BOCA building code. It will also be seismically checked in accordance with NRC Regulatory Guide 1.143.

The foundation will consist of a reinforced concrete slab on grade. The slab will be designed in accordance with NRC Regulatory Guide 1.143. Nominal floor elevation will be 305'-0", with exterior edges of the foundation slab turned down below the frost line. A 4-inch curb will be provided to contain any fire water released within the building. All construction joints. will have a water stop. All shield walls in the building will be reinforced concrete. 


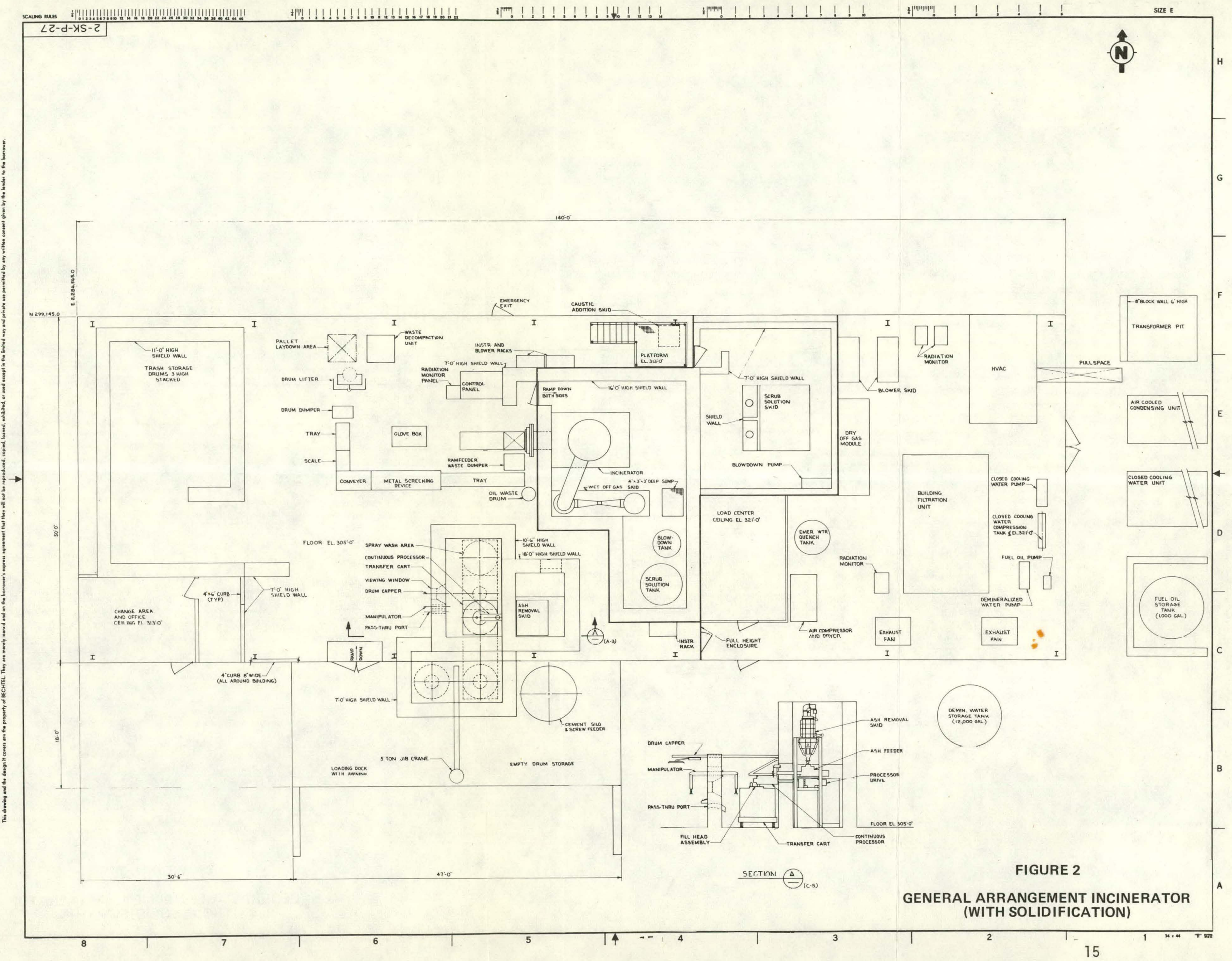




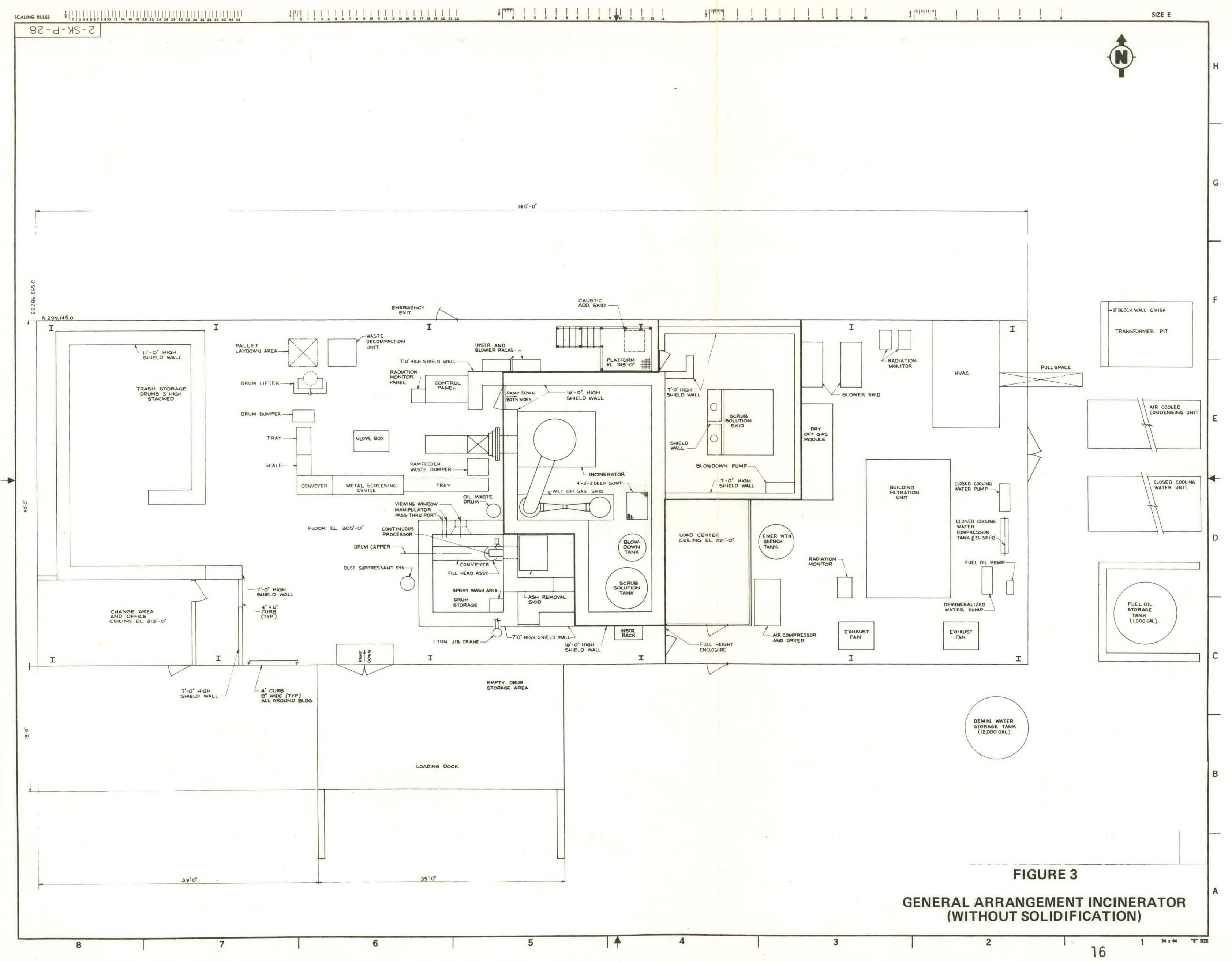


A11 floors and walls, except those in the load center room and support systems equipment room, will be sealed with epoxy up to the curb height. The following areas will have the full height of the walls coated with epoxy to allow for decontamination:

\section{Trash Storage}

2. Incinerator

3. Scrub Solution

\section{Ash Handling}

An 8-feet-high galvanized steel fence will enclose the incinerator facility for security purposes. There will be three barbed wires along the top of the fence, and a motorized gate will allow personnel and vehicle access.

\section{Waste Receiving And Preparation}

Waste will be brought to the incinerator facility in 55-gallon drums and will be unloaded on an 18 foot $\times 47$ foot covered loading dock (an 18 foot $\times 35$ foot uncovered loading dock for the facility option without solidification). A shielded forklift will transpoirt the drums (on a pallet) inside the building to a shielded storage area designed to hold one day's worth of waste. The shielded forklift will also be used to bring drums from storage to the waste preparalioli area. A manual drum lifter will be used to transport. individual drums to a hydraulic drum dumper. If the drum contains compacted waste, the drum will be transported to a hydraulic drum dumper equipped with a vibrating mechanism, which will unload the waste into doubled plastic bags. A tent will enclose the compacted drum unloading process to minimize the spread of any possible airborne contamination. If the drum contains nơncompacted waste, a hydraulic drum dumper will unload the waste (already packaged in doubled plastic bags) onto a stainless steel receiving tray. Bag breakage is not expected to be a problem. (The Ontario Hydro Bruce Nuclear Power Development site loads waste packaged in plastic bags into their incinerator, 
and has had no problem with bags breaking and causing airborne contamination. ${ }^{a}$ ) If a bag rip does occur, however, the torn bag can be taped or enclosed by a larger plastic bag.

After the waste bag has been placed on the stainless steel tray (from either the compacted or noncompacted drum dumper), the waste will be manually pulled to an adjacent weighing scale. The weighing scale is a 46 inch $\times 38$ inch load cell platform with remote digital readout. (The waste is weighed in order to maximize incineration efficiency.) After weighing, the trash is manually pulled onto the conveyor of an $x$-ray metal screening device equipped with a TV monitor. The metal screening device surveys the trash for large metal or other noncombustible articles that could hinder the ram feeding operation (into the incinerator) or the eventual transfer of ash from the incinerator. If an item must be removed; the bag is placed into a cart located at the exit from the metal screening machine, and wheeled to a glove box where the item is removed. A bag that does not require sorting is manually pulled from the metal screening machine along another stainless steel tray to the ram feeder waste dumper. The trash bag is pulled into the dumper, the operator activates the dumper, and the bag is automatically loaded into the ram feeder.

Dewatered resins, packaged in plastic bags, will be fed to the incinerator using the ram feeder waste dumper. Waste $0 i 1$ will be transported to the facility in 55-gallon drums; the oil will be pumped directly from the drums to the incinerator through a special injection port on the incinerator.

Waste oil injection will be at the rate of 1 gallon per hour when burned with other incinerator trash.

a. See Experience From Existing CAI's, page 37. 
Transuranic waste will only be incinerated such that the ash will not exceed 10 CFR 61 limitations (10 nanocuries per gram). A11 waste will be analyzed for transuranic content by plant (administrative) procedures prior to transport to the facility. Any waste that could yield ash with transuranic content above these limitations will not be sent to the facility; new plant procedures will have to be developed for this analysis. Finally, there will be no decontamination of drums used to transport waste to the facility. Decontamination of waste drums, if required, will be performed elsewhere.

A self-contained emergency eyewash and shower will be provided for personnel decontamination and safety.

\section{Incinerator System}

The Helix Process Systems incinerator system was used as a basis for determining facility and support services needs, although the use of equivalent incinerator systems by other manufacturers is not expected to significantly impact the costs and project schedule presented in this study. The Helix system includes an incinerator, wet off-gas scrubbing components, dry off-gas module, induced draft blowers, and an ash removal system. The Helix incineration system consists of four subsystems mounted on seven skids. The four subsystems are the incineration, off-gas, scrub solution, and ash removal systems. The skids consist of an incinerator, ash removal, wet off-gas, dry off-gas, induced air blowers, scrub solution, and caustic addition components. Helix also suppliès a blowdown tank, a scrub solution tank, an emergency water quench tank, and instrument racks; a control panel for system operation is also provided.

Except for process and effluent radiation monitors and an effluent opacity monitor, Helix provides all process instrumentation required for operation of the incinerator system. The high level alarms in the TMI-2 main control room for the radioactive liquid tanks, however, are excluded from the Helix scope. In addition, except for ducting between the incinerator and the quench column, Helix provides no interconnecting piping, tubing, or wiring between skids. 
Support requirements of the Helix incineration system are electrical power, cooling water, fuel oil, compressed air, demineralized makeup water, and building ventilation. These are described later.

The incinerator off-gas effluent to the atmosphere will be monitored for opacity per the requirements of Pennsylvania's Department of Environmental Resources. Opacity will be recorded and alarmed in the incinerator facility. In addition, an alarm contact that actuates at 20 percent opacity will be wired to the plant computer.

Caustic addition solution will be prepared by mixing bags of sodium hydroxide with demineralized water in the caustic addition tank until a 0.25 (by weight) percent solution is obtained. Considering the restricted PVC and rubber content of the waste feed to the incinerator facility (designed for approximately 0.5 percent by weight), it is estimated that approximately 25 gallons of caustic solution will be used per week.

Heating, Ventilating, and Air-Conditioning (HVAC) System

HVAC is provided by a ducted, once-through supply and exhaust system. More air is exhausted than supplied to ensure against exfiltration of the potentially contaminated building atmosphere. Supply air is provided by a 15,000 cfm air handling unit consisting of filters, an electric heating coil, a direct-expansion (DX) cooling coil, and a supply fan. The DX coil is part of a refrigeration system which includes an outdoor, air-cooled condensing unit and refrigerant piping. Building exhaust is through an $18,000 \mathrm{cfm}$ high efficiency particulate air (HEPA) filter train and exhaust fan; a redundant exhaust fan is provided for reliability. Differential pressure indication and alarm for the exhaust HEPA filter train are provided on the incinerator control pane1. Building exhaust will be monitored for radioactivity. The HVAC system is schematically shown in Figure 4 . (Figure 11 provides a legend for all symbols and identifications used on the system.schematics.) 


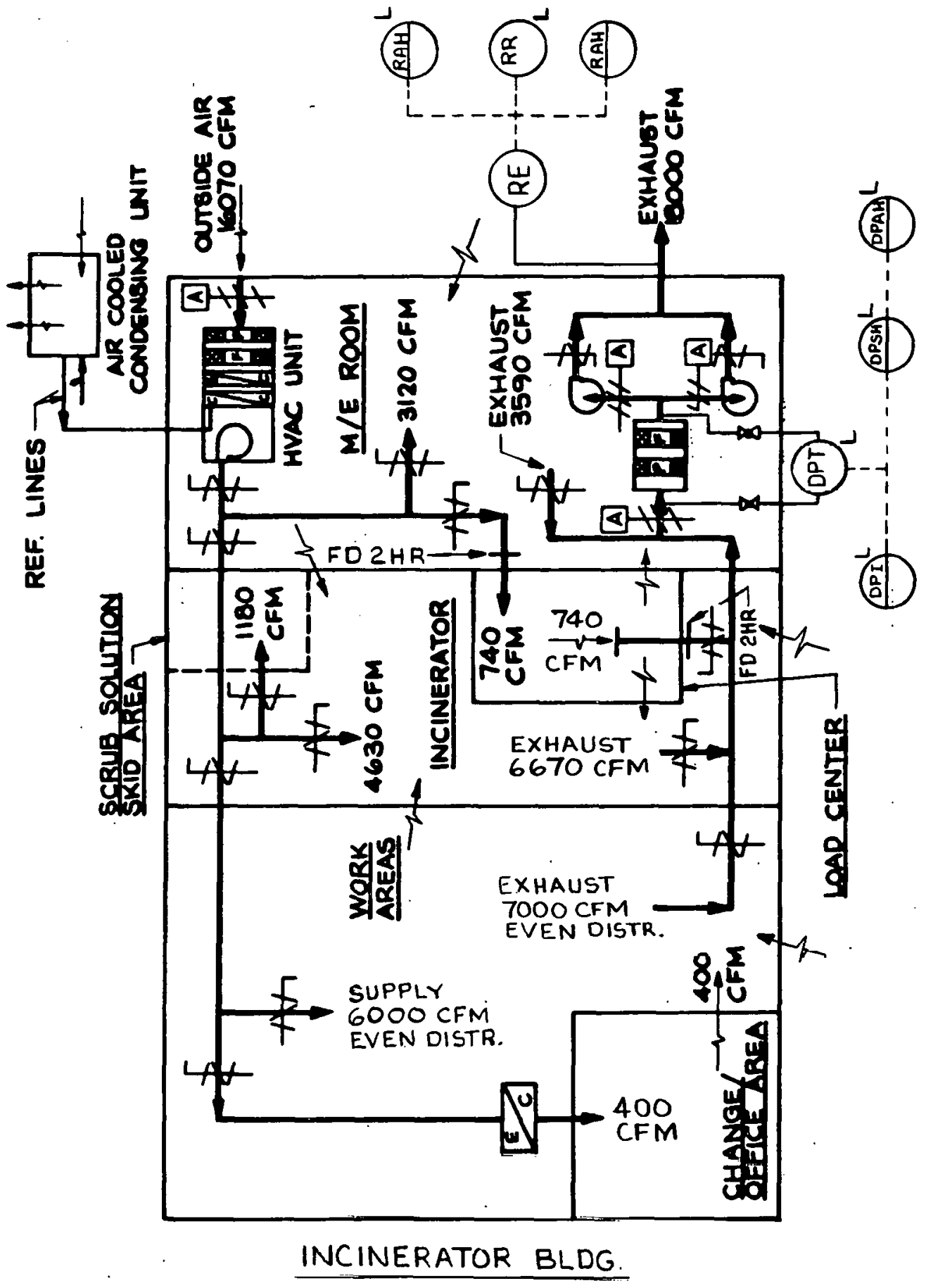

Figure 4. HVAC Schematic 


\section{Compressed Air System.}

The compressed air system is used to supply air to the Helix instrumentation on the wet and dry off-gas skids, the emergency quench water tank, the ash transfer skid, and the building HVAC system. The system consists of a 5-hp compressor capable of delivering $20 \mathrm{scfm}$ between 80 and $200 \mathrm{psig}$, an $11 \mathrm{ft}^{3}$ receiving tank, an air dryer with inlet and outlet filters, and required piping and valves. A low pressure alarm will be provided on the incinerator control panel. The compressed air system is schematically shown in Figure 5.

\section{Demineralized Water System}

The demineralized water system provides continuous makeup water to the scrub solution tank, and supplies fill and/or flush water for the emergency fill tank, caustic addition tank, liner or drum wash station. (only in ash handling or solidification area), closed cooling water compression tank, blowdown tank and blowdown process line, two water supply locations, incinerator ram feeder, and cement mixing for ash solidification. ${ }^{a}$ A stainless steel transfer pump, capable of pumping $20 \mathrm{gpm}$, will recirculate demineralized water to a 12,000-gallon fiberglass storage tank located outside the incinerator building.

The storage tank will be insulated and heated to protect it against freezing. All piping runs will be of stainless steel. The demineralized water storage tank is sized to hold one week's supply of water. Weekly refills will be via tank truck connections. Level indication, temperature indication, a low level alarm for the storage tank, and control for the transfer pump will be provided on the incinerator control panel. The demineralized water system is schematically shown in Figure 6.

a. The use of demineralized water is required by Helix for compatibility with materials used in the incinerator system. 


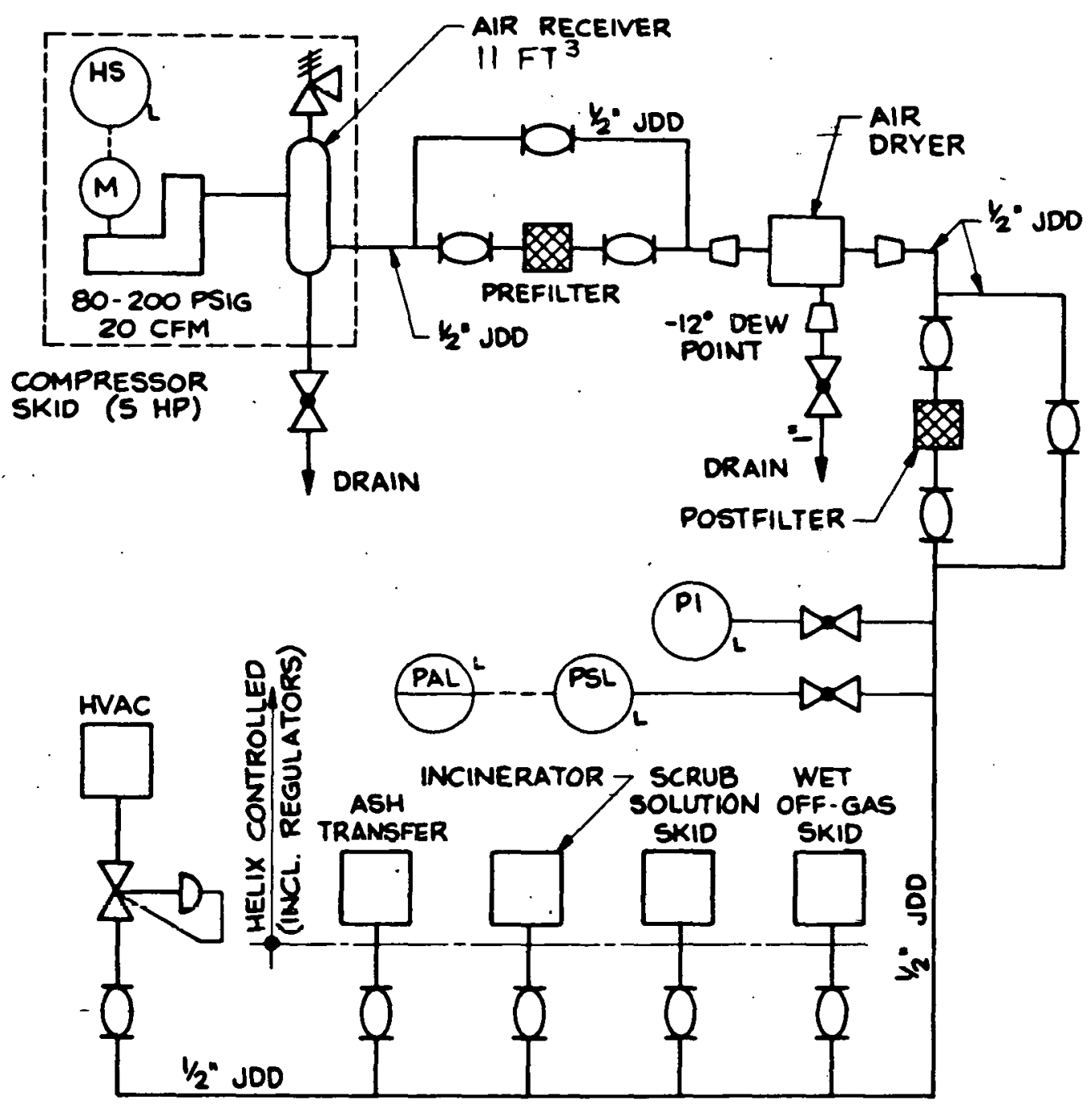

Figure 5. Compressed Air System Schematic 
NOTES:

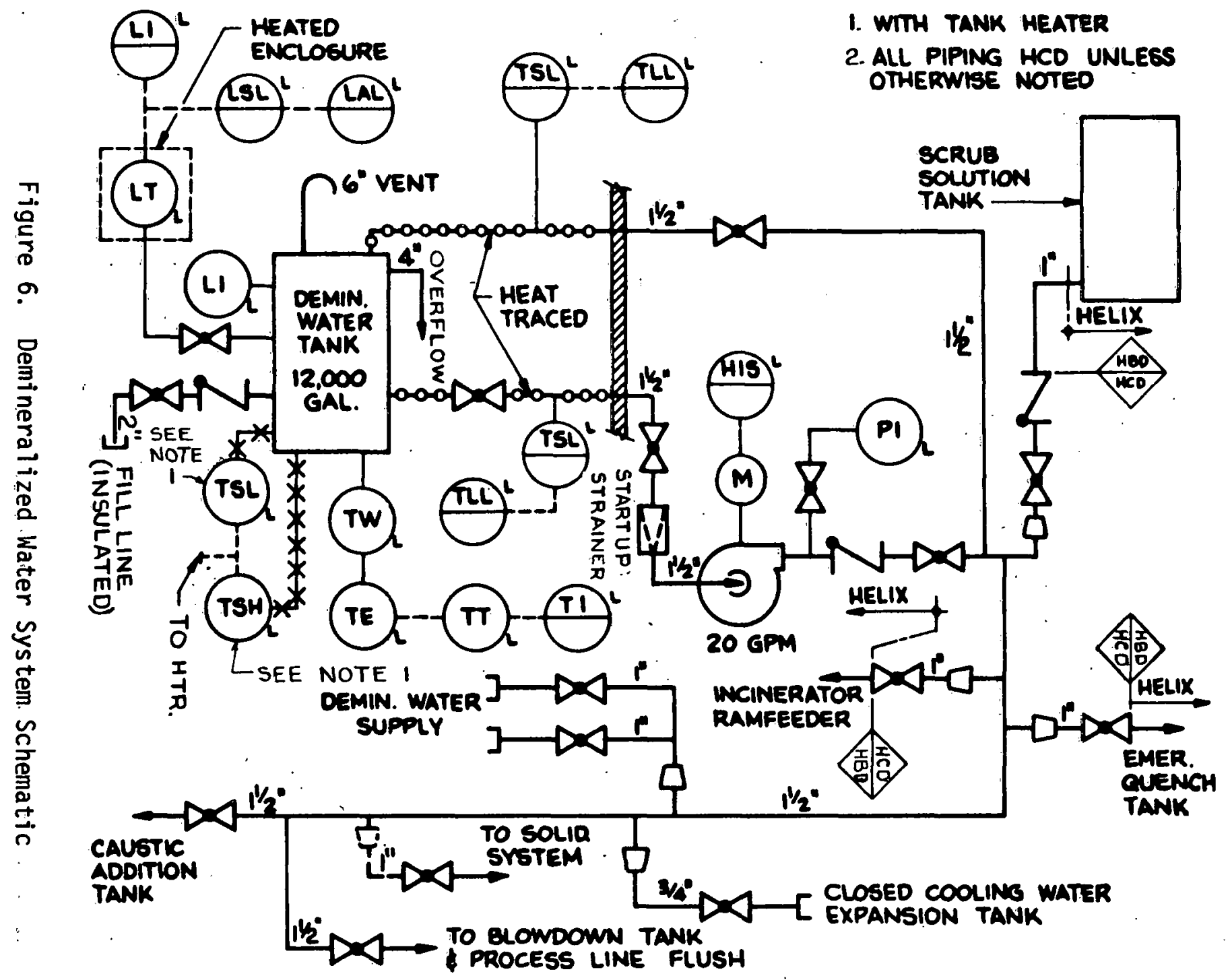




\section{Closed Cooling Water System}

The closed cooling water system will supply cooling water to the Helix scrub solution cooler and wet off-gas condenser. The cooling loop is closed in order to prevent direct releases of radioactive scrub solution leaks to the environment. The cooling water system consists of a $10 \mathrm{hp}$, carbon steel pump (capable of delivering $180 \mathrm{gpm}$ at a minimum pressure of $25 \mathrm{psig}$ ), a $3.78 \times$ $10^{6} \mathrm{Btu} / \mathrm{hr}$ air-cooled heat exchanger' (located adjacent to the building), a 30-gallon compression tank, an air separator, and required carbon stee 1 piping and valves. A conductivity cell monitors the cooling water for possible scrub solution in-leakage. Cooling water flow and temperature are monitored locally. Pump controi and alarms for low flow, low level, and high conductivity will be provided on a local control panel. A trouble alarm will be provided on the incinerator control panel. The closed cooling water system is schematically represented in Figure 7.

\section{Fuel 0 il System}

The fuel oil system provides a 3 psig supply of fuel to the incinerator. The system consists of a 1/4-hp carbon steel pump ( $1 \mathrm{gpm}$ ), a 1,000-gallon carbon steel fuel oil tank (located adjacent to the incinerator building), and required carbon steel piping and valves. While the pump recirculates the fuel oil to the fuel oil tank, a pressure regulating valve delivers fuel at a pressure of 3 psig to the incinerator. The fuel oil tank is sized for one week's supply of fuel to the incinerator. Weekly refills will be via tank truck connections. The outside fuel pump suction line is heat traced to preheat the fuel during cold weather. Level indication and low-level alarm for the fuel oil storage tank and control for the fuel oil pump will be provided on the incinerator control panel. The fuel oil system is schematically shown in Figure 8.

\section{Blowdown Systcm}

The blowdown system provides for intermediate storage of scrub solution blowdown and a means for transferring the scrub solution blowdown from the 
NOTES:

I. WITH AE INSTR.

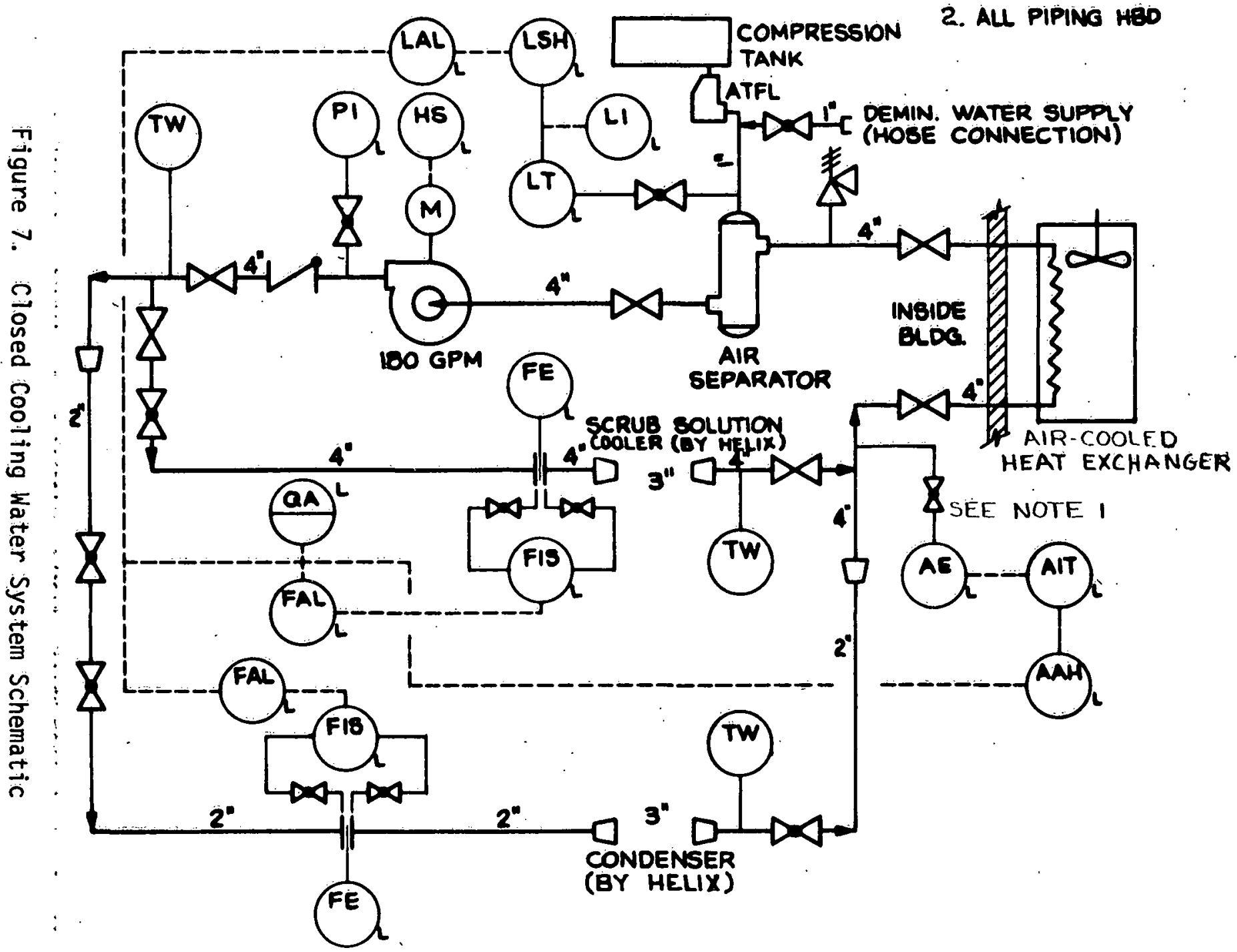




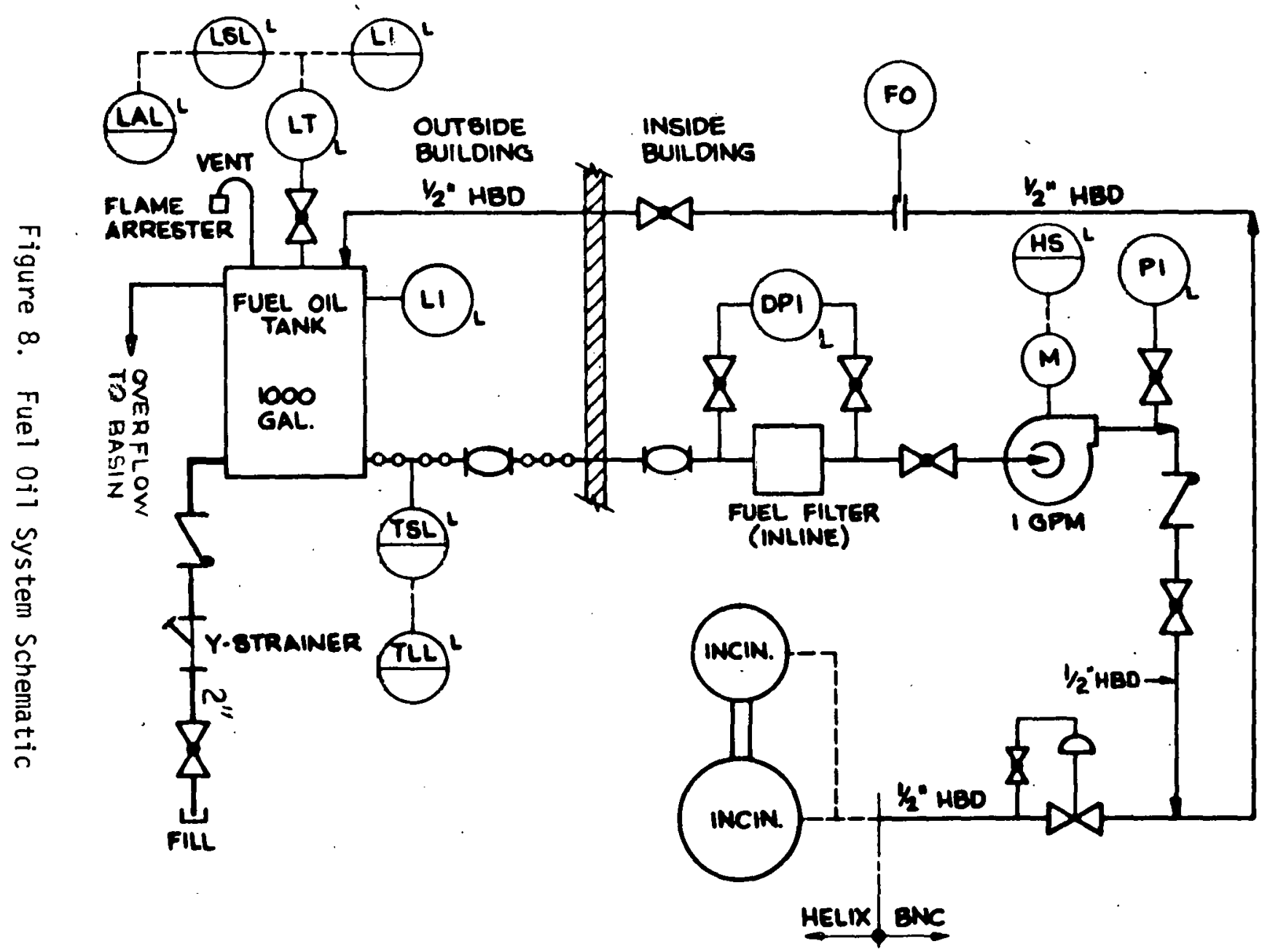


facility (via solidification or some undefined liquid transport system. outside the building). The system consists of the Helix blowdown tank, a 1/2-hp Carpenter 20 stainless steel: pump (capable of pumping $25 \mathrm{gpm}$ ), an inline sample bottle on the recirculation line, and two flushing connections. Piping and valves in contact with blowdown fluids are lined carbon steel. A high level alarm that annunciates in the Unit 2 main control room is provided in addition to normal Helix instrumentation. Local control is provided for operation of the pump. The blowdown system is schematically shown in Figure 9.

A 4 foot $\times 3$ foot $\times 3$ foot sump is provided in the scrub solution and blowdown tank area to collect tank overflows and area leakage. A sump high level alarm will be provided on the incinerator control panel. A portable pump will be used to remove wastes from the sump; this pump is not included in the cost estimate. Provisions for a drain system were not considered to be cost effective. The need for and use of additional sumps, however, should be considered in the detailed design of the facility.

\section{Fire Protection System.}

Principal facility fire protection will be provided by a wet pipe, fused head sprinkler system, backed up by two 1-1/2-inch hose reels and eight portable fire extinguishers. Fire water supply to the facility will be via a 500-foot extension of the existing 12-inch plant fire water main, and will include a new outdoor hydrant and hose house. Ionization and rate-compensating fire/ smoke detectors will alarm locally and in the Unit 2 main control room. The fire protection system is schematically shown in Figure 10.

\section{Radiation Monitoring}

Radiation monitoring will be supplied for area radiation, process monitoring, and effluent monitoring. Area radiation monitors will be in the following locations:

1. Near the office, at the waste entrance and exit point 
- reach roo

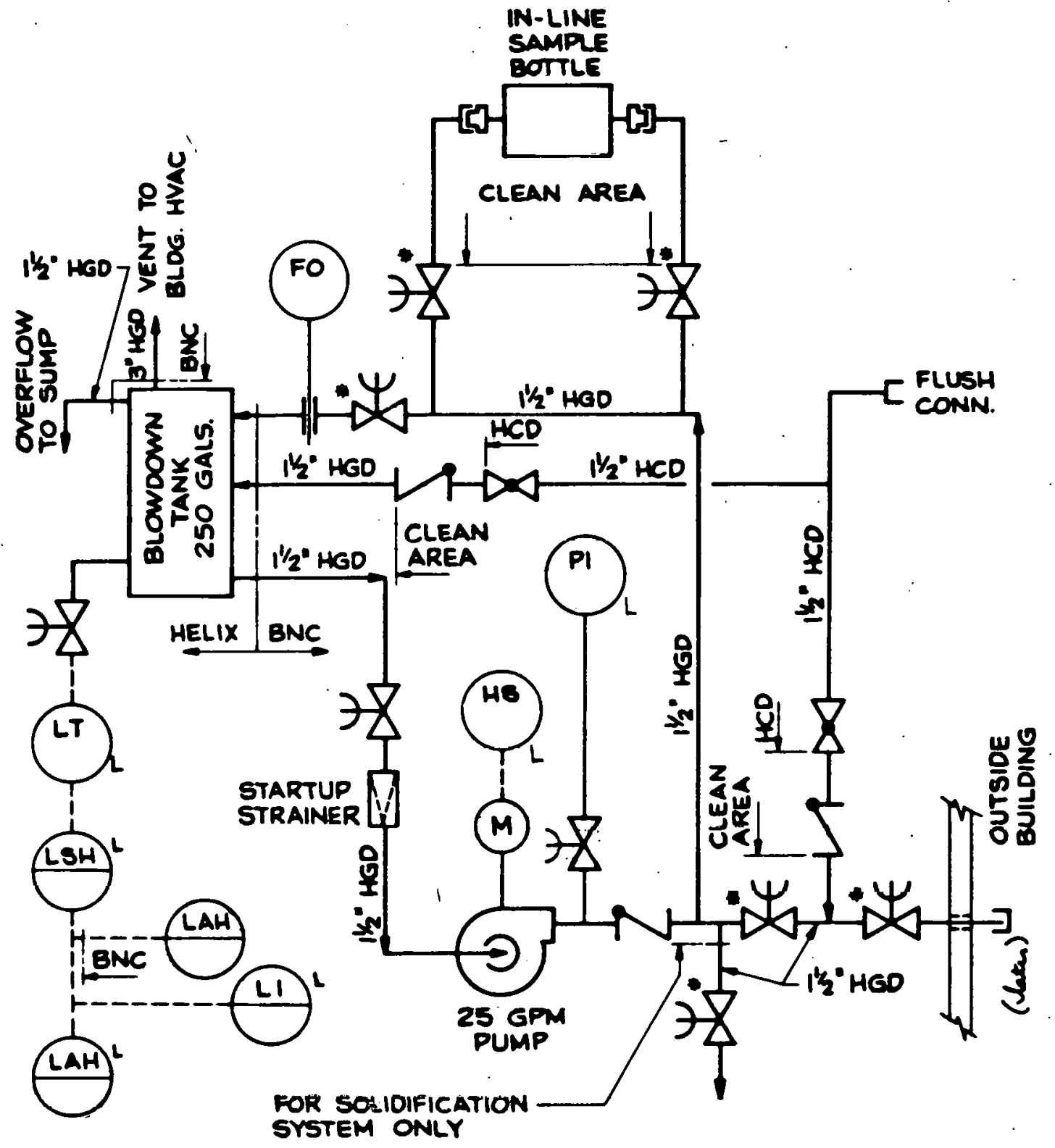

Figure 9. Blowdown System Schematic 


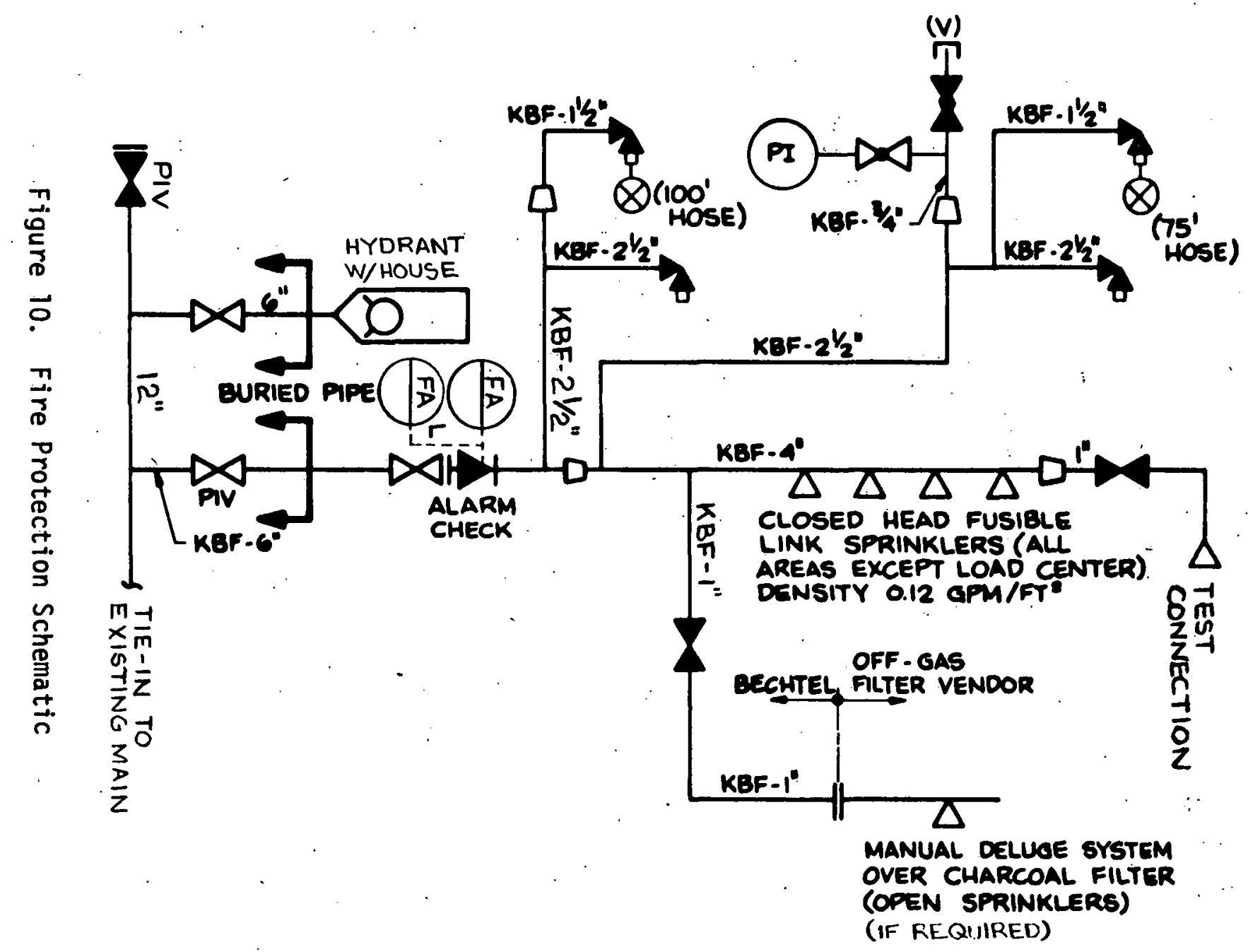




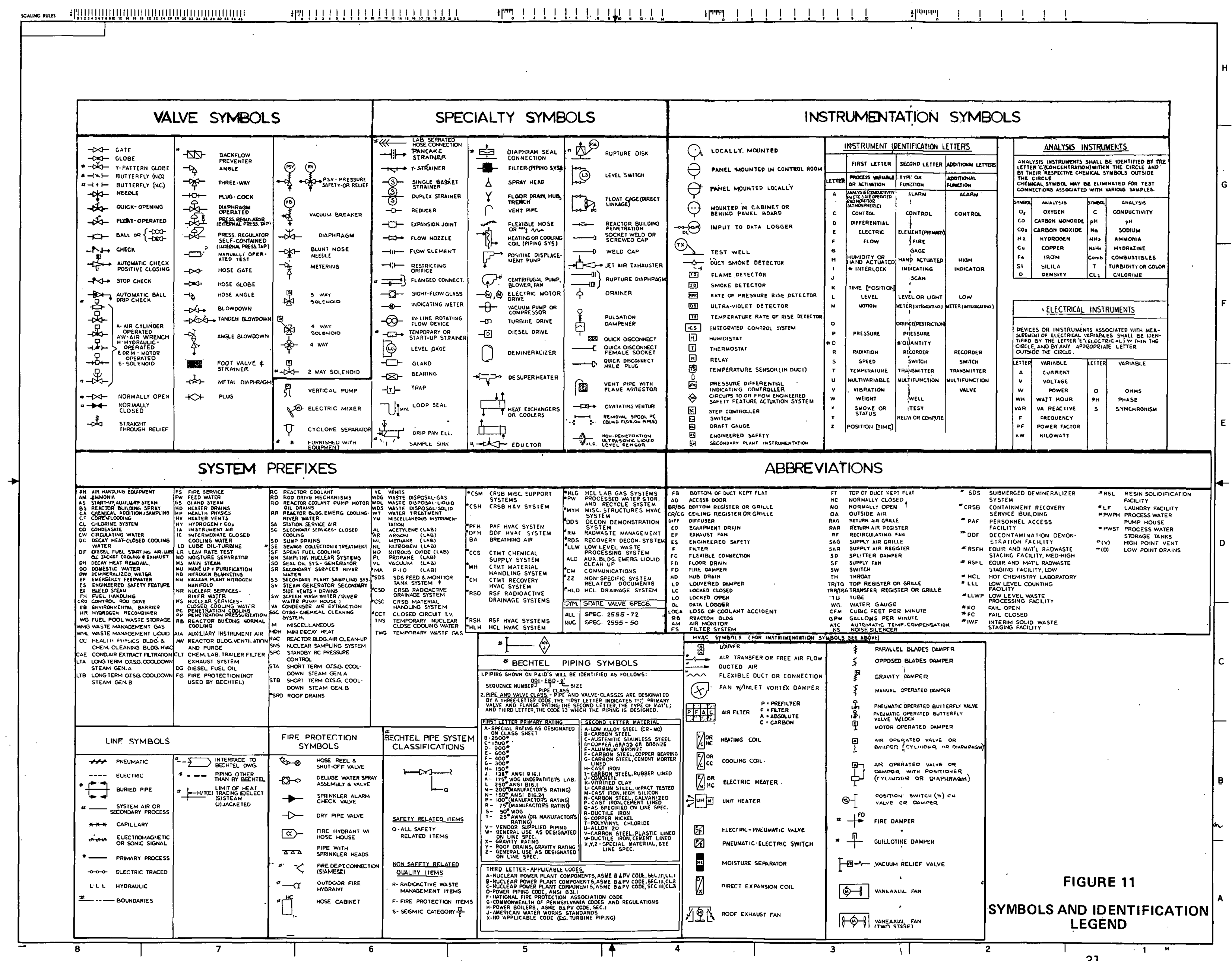


2. Control panel area (common to the incinerator loading and waste sorting area)

3. In the passageway to the support services area (near the ash handling/solidification area)

Process monitors will be located on each scrub solution filter and the scrub solution blowdown tank to determine. the need for changeout of filters and to monitor bulk radioactivity of the scrub solution. Effluent monitors will be located at the facility HVAC release point and the off-gas release point; there will be two monitors at the off-gas release point. The area radiation monitors and the process monitors will alarm at the incinerator control panel. The effluent monitors will alarm at the incinerator control panel and in the Unit 2 main control room. The effluent monitors will be continuously recordied.

\section{Shielding}

Using the values estimated for the isotopic content of incinerator feed ${ }^{a}$ and the design bases ${ }^{b}$ specified in this report, shield wall thicknesses were estimated. The walls were sized to maintain the following dose limits:

1. $\leqq 0.5 \mathrm{mrem} / \mathrm{hr}$ on the outside of the building

2. $\leqq 2.5 \mathrm{mrem} / \mathrm{hr}$ in the general working area

3. $0.5 \mathrm{mrem} / \mathrm{hr}$ in office

4. $\leqq 0.1 \mathrm{mrem} / \mathrm{hr}$ in frisking area
a. See Isotọpic Consistency, page 8.
b. See Appendix A, page A-1. 
The estimated wall thicknesses are:

1. Waste storage area - 15 inches

2. Ash handling area -18 inches

Based on these estimates, the following wall thicknesses were used in this study:

1. Waste storage area -2 feet

2. Incinerator area - 2 feet

3. Ash handling area - 2 feet

4. Office and frisking area - 6 inches

5. Filter area - 1 foot

These wall thicknesses are comparable to what would likely be found in an operating power plant. Specifically, several projects were checked regarding their waste storage areas and were found to have walls of 2 feet or more in thickness.

An estimate of the dose to an individual due to skyshine from the facility was made and was found to he less than 1 mrem per year, which, when combined with other sources from the site, will satisfy the requirements of 40 CFR Part 190 .

\section{Electrical Power}

Electrical power for the incineration facility will. be provided from an existing 13.2-kV overhead line via a 13.2-kV to 480- $\dot{V}$, 3-phase, pad-mounted transformer adjacent to the incinerator building. Power from the transformer to the incinerator service entrance equipment will be via underground ducts. 
In addition, a second source of 480-volt power from Unit Substation 2-51 in the circulating water pump house will be provided for redundant service to the induced draft fans (two) and the scrub solution recirculation and transfer pumps (four). Independence of the two power sources is ensured, since the electrical source of Unit Substation 2-51 (backup source) is a $230 \mathrm{kV}$ grid via station auxiliary power transformers, and the normal source of 13. $2 \mathrm{kV}$ power is obtained from an offsite substation. This offsite substation is separated from the $230 \mathrm{kV}$ grid by several transformations of voltage. A motor control center (MCC) with a required service entrance disconnect switch will be provided to supply all facility electrical loads. A section of the MCC will service redundant loads and will be connected to the main MCC section with an automatic transfer switch. All electrical loads will normally be supplied from the $13.2-k V$ overhead line.

\section{Lighting and Communications}

The normal lighting system for the incinerator facility will provide adequate illumination levels and convenience power for operating and service conditions. In addition, it serves as a distribution system for miscellaneous small load requirements. This system consists of a complete distribution network of cables, raceways, transformers, lighting panels, lighting fixtures, receptacles, and switches. Lighting levels will be $20 \mathrm{fc}$ in mechanical equipment room areas, $30 \mathrm{fc}$ in process areas, and $100 \mathrm{fc}$ in the office area. Exterior lighting levels will be in accordance with existing site surveillance requirements.

An emergency lighting system will provide emergency lighting for egress routes and will consist of individual, self-contained, sealed-beam battery units (8-hour rated). These battery units are connected to the normal ac source to maintain battery charge, and automatically transfer to their. internal batteries upon loss of ac power. Illumination levels will be as required by the Pennsylvania Department of Labor and Industry Fire and Panic Regulations. 
Communications will be provided by equipment ties into the plant public address system, an intercom (for internal communications only), and telephone service. Telephone service will be provided in the office and at the incinerator control panel.

\section{Solidification}

For the incineration facility design option with integral solidification of waste ash, a Teledyne Energy Systems (TES) cement solidification system was selected. Selection of TES was based on the familiarity of Teledyne with the Helix incinerator system and the fact that Teledyne is currently involved with the marketing solidification systems that interface with the Helix equipment. Bechtel Northern Corporation (BNoC) does not necessarily recommend the TES solidification system; however, the space requirements for this system are considered to be typical of allowances necessary for other systems. The proposed system (refer to Figure 2) will solidify and package the ash in $50 \mathrm{ft}^{3}$ liners. The liners will be transferred to the loading dock storage area by an electrically driven cart. The filled liners will be transferred from the building, using a 5-ton jib crane mounted on the loading dock, by lifting the liners over a 7-foot-high shield wall constructed on the outside of the building. The major components of the TES system for which a space allowance is made are:

1. Vibrating screw feeder

2. Continuous processor (mixer)

3. Fill head assembly

4. Cement silo and screw feeder

5. Transfer cart and turntable

6. Washdown station 
7. Drum capper

8. Shielded viewing window

9. Master-slave manipulator

10. Progressing cavity pump

\section{Ash Handling (Without Solidification)}

For the incinerator facility design option with provisions for packaging the waste ash for transport from the building, a similar system to the TES solidification system will be used, except that the $50 \mathrm{ft}^{3}$ liners used for solidification will be replaced by 55-gallon drums. In addition, all operations, including the lifting of the drums, will be performed inside the building. Instead of mixing cement and water (or blowdown) with the ash, a dust suppressant will be added to the ash through the vibrating screw feeder. The dust suppressant will prevent dusting and airborne contamination problems after the fill head assembly is removed and before the drum is capped. The drums will be moved via conveyor through a filling, capping, and swiping sequence. If drum decontamination is required, it will be moved to a washdown station. The washdown station has an integral sump; a sump water recirculation pump and filter is provided to permit reuse of the washdown water. The filled drum will be lifted over a 7-foot-high shield wall and onto a shielded forklift by a 1-ton jib crane. The shielded forklift will transport the filled drums out of the building. A conceptual design of the ash handling system is shown in Figure 3 .

\section{Change Area and Office}

The change area and office will provide space for administrative activities and changing of anticontamination clothing. 
In designing a CAI facility for TMI-2, experience from existing or planned controlled air incinerators was considered. Knowledge of these incinerators was gained through literature, phone conversations, and/or trips to the facilities. The incinerator systems studied included those located at the Los Alamos Scientific Laboratory (LASL), Savannah River Laboratory (SRL), Westinghouse Nuclear Fuel Fabrication, and Ontario Hydro's Bruce Nuclear Power Development (BNPD) facilities.

\section{Los Alamos Scientific Laboratory (LASL)}

LASL currently uses a controlled air incinerator to burn transuranic (TRU). contaminated wastes. A wet off-gas scrubbing system is used, and a pneumatic transport system transfers ash from the incinerator to an ash hopper.

Separate HEPA filter trains are used for the incinerator process off-gas, and for the incinerator building and receiving/sorting glove box exhaust ventilation.

LASL presently uses 15 pounds per hour of steam in the lower (primary) incinerator chamber to promote chloride and carbon conversion (as $\mathrm{HCl}$ and $\mathrm{CO}_{2}$ to the off-gas). They will use 150 pounds per hour of steam in the incinerator if a fast shutdown is necessary (an emergency quench water tank is used for the off-gas portion of the system). Steam has been tried in the incinerator as a means of temperature control, but it was found that the temperature in the incinerator did not respond well to steam addition. Based on this experience, LASL does not recommend that steam be used for temperature control. Steam is also not recommended for fire suppression at the incinerator ram feeder opening due to the steam hitting cold metal; LASL uses argon for fire suppression at the ram feeder inlet to the incinerator.

a. As a process control, Helix recommends the use of demineralized water for this function. 
The waste feed at LASL normally contains about 30 percent rubber and 10 to 15 percent PVC; however, blowdown of scrub solution due to neutralization salt buildup has not yet been required. (If required, blowdown because of salt buildup in the scrub solution would be actuated by an increase in the specific gravity of the scrub solution to approximately 1.15). The reason no blowdown has been necessary due to salt buildup is believed to be because a constant blowdown of approximately 1 gallon per minute from the scrub solution is required due to process pump mechanical seal water in-leakage. LASL sends all their scrub solution blowdown to a separate onsite liquid radwaste facility for processing.

Waste is loaded into the incinerator at LASL in cardboard boxes. The boxes are assayed for transuranic content and are surveyed for metal by an $x$-ray machine prior to incineration; any metal or large noncombustibles are removed in a glove box.

\section{Bruce Nuclear Power Development (BNPD)}

BNPD currently burns low level waste generated from their nuclear power utility with a controlled air incinerator. A dry off-gas system is used. Ash is gravity dropped from the incinerator into $88 \mathrm{ft}^{3}$ rectangular boxes, which are then manually shut and buried in trenches. Separate HEPA filter trains are used for the incinerator process off-gas and for the incinerator building ventilation exhaust.

Waste is loaded into the incinerator in plastic bags (polyethelene); $530 \mathrm{ft}^{3}$ of waste is loaded and then is burned for approximately 30 hours. The ash is then removed and a new $530 \mathrm{ft}^{3}$ batch is loaded. BNPD has had no problem with the plastic bags breaking and causing airborne contamination; however, they have had a few "burps" from the incinerator that caused some minor airborne contamination. The plastic bags of waste are surveyed prior to incineration for metal. If any metal is detected, the bag is sent to be compacted; no attempt is made to remove the metal.

There is no off-gas treatment of acid gases from burning PVC and rubber at BNPD; only about 1.5 percent PVC is burned, however. 
SRL is presently developing two controlled air incinerators, one for TRU waste and one for low-level contaminated waste. The following information is based on the low-level waste incinerator.

The SRL incinerator will use a dry off-gas system. The dry off-gas system will neutralize $\mathrm{HCl}$ and $\mathrm{SO}_{2}$ by the addition of $\mathrm{Na}_{2} \mathrm{CO}_{3}$; approximately 8 percent PVC and 19 percent rubber are expected to be burned. The waste will be loaded into the incinerator in cardboard boxes. The boxes will be surveyed by $x$-ray for metal or other large noncombustibles; if any are found the box will be sent back to the SRL waste packaging facility for repackaging. Ash will be gravity loaded from the incinerator into drums. SRL will use steam for carbon conversion and temperature control in the incinerator.

\section{Westinghouse}

Westinghouse presently uses a controlled air incinerator to burn uranium contaminated waste at their Nuclear Fuel Fabrication Facility in Columbia, S.C. A wet off-gas scrubbing system is used. Waste is loaded into the incinerator in plastic bags. Ash is manually scraped into 5-gallon drums from the incinerator. Steam is used for carbon conversion and fire suppression at the incinerator ram feeder opening. Westinghouse has not had to blowdown their scrub solution due to salt buildup since PVC material is not included in the waste feed. No $x$-ray is performed on the input waste, only a vișual search is done. 


\section{DESIGN ASSESSMENTS}

The following are assessments of the effect of waste composition on incineration volume reduction with and without solidification, the effect of environmental releases on the incinerator building exhaust filtration, and the effects of alternate isotopic content of the waste feed on building HVAC and shielding requirements. An evaluation of quality assurance requirements for the incinerator facility is also given.

\section{Effect of Waste Composition On Incineration Volume Reduction}

\section{Without Solidification}

Volume reduction factors for waste incineration have typically ranged from 20:1 (waste to ash) to as high as 100:1 and more, depending on the density and composition of the waste being burned. The Los Alamos Scientific Laboratory (LASL) incinerator has experienced volume reduction factors normally in the range of $40: 1$ to $50: 1$. Helix advertises a volume reduction of $40: 1$ for their incinerator. Since the Helix incinerator is based on the LASL CAI process, a 40:1 volume reduction of waste to ash is considered likely at TMI-2. However, blowdown waste caused by burning PVC and rubber adversely affects the high volume reduction achieved by incineration. The volume of blowdown created from salt buildup in the scrub solution due to incineration of PVC and rubber is estimated to be at least equal to the volume of PVC and rubber originally incinerated. 5 The volume of blowdown will probably be greater than this, depending on the weight percentage of salt build up allowed in the scrub solution (from 3 percent to 10 percent by weight); Helix recommends 3 percent as a conservative amount to protect against corrosion. Volume reduction factors associated with the incineration of resins are expected to be approximately 15:1; no appreciable by-products are expected from the burning of waste 0 il. Assuming that 9 percent of the total TMI-2 combustible waste quantity (not including resins and waste oil) is PVC and rubber, ${ }^{a}$ and assuming a volume reduction factor of 15:1 for resin, complete volume reduction for $0 i 1$, and 40:1 volume reduction for all other waste, an

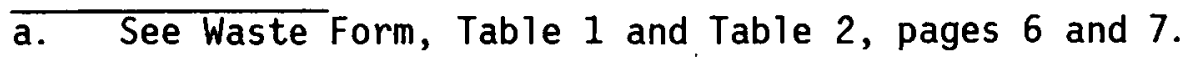


overall volume reduction factor (waste to ash and blowdown) of 10:1 is achieved. If other nonsulphur-chlorine materials (e.g., polyethelene, cloth, etc.) are substituted for the PVC and rubber wastes, an overall volume reduction of approximately 46:1 (waste to ash) could be achieved.

A brief investigation indicates that all PVC items are replaceable, but some of the substitutes are different in shape, texture, and/or form. It is also known that at least one other utility (Duke Power) has plans for a PVC. reduction program. The cost of such a program has not been investigated.

\section{With Solidification}

Based on typical cement solidification of waste, a volume increase of approximately one and two-thirds can be expected. The effective volume reduction yielded by solidification of incineration by-products with cement is expected to be 6:1 when PVC and rubber are burned, and 27:1 when PVC and rubber are replaced by other materials. The use of Dow polymer media, however, may improve the effective volume reduction yielded with solidification. If solidification is required, other methods and media for ash solidification should be investigated during detailed design engineering.

\section{Effect of Environmental Releases On Incinerator Building Exhaust Filtration}

The annual offsite dose resulting from routine airborne releases from the incinerator facility via the normal HVAC system was estimated, based on an unfiltered exhaust flow rate of 18,000 cfm. Following an approach taken in the Programmatic Environmental Impact Statement (PEIS), 6 the airborne radionuclide source term released via the normal HVAC system was assumed to be 0.1 percent of the incinerator throughput. A reassessment of this ( 0.1 percent) source term, based on applicable industry experience and/or regulatory guidance (if available), should be made during detailed engineering to determine if a lower release fraction is justified. 
The total radioactivity handled was based on an incinerator feed rate of $350 \mathrm{lbs} / \mathrm{hr}, 24$ hours per day, 5 days per week, 52 weeks per year. The isotopic concentration used was as given in the waste stream characterization section of this report.

Using the TMI-2 Offsite Dose Calculation Manual, 7 the annual dose at the nearest residence was calculated to be 1.54 mrem due to inhalation. Based on the Offsite Dose Calculation Manual and the PEIS, the annual dose at the nearest residence due to the vegetable path is as much as a factor of 100 greater than that due to inhalation. This would exceed the allowable dose of 15 mrem annually to any organ due to airborne releases. Therefore, based on this and the assumptions stated above, filters are required in the building ventilation exhaust. These filters will reduce the offsite dose by at least a factor of $10^{3}$.

\section{Effect of Alternate Isotopic Content of Incinerator Feed On Building} HVAC and Shielding

The isotopic content of incinerator feed used in the environmental release analyses equates to approximately $400 \mathrm{Ci}$ per year going through the facility and is believed to be conservatively high. If the quantity of radioactivity to be processed through the facility was $50 \mathrm{Ci}$ per year, the offsite dose from inhalation would be approximately $0.2 \mathrm{mrem} / \mathrm{yr}$, with a dose from the vegetable pathway up to $20 \mathrm{mrem} / \mathrm{yr}$. This would exceed allowable $1 \mathrm{imits}$, and filters would still be required on the building exhaust. The shield wall thicknesses, however, would probably be reduced, in most cases, by up to 7 inches. 


\section{LICENSING}

The incinerator facility will require various permits and approvals in order to be built and operated. The permits and approvals will need to be obtained from both the state and the NRC, as described below. Also discussed are the major requirements impacting the incinerator facility.

\section{$\underline{\text { State }}$}

The Pennsylvania Department of Environmental Resources (DER), requires permitting or written approval for the construction, assembly, installation, modification, or operation of any stationary source of air contamination. There are two permits, one to construct and one to operate.

The permit application for construction will need to address the following:

1: The location of the source

2. Information necessary to evaluate the air contamination aspects of the source

3. Details of the monitoring, emission record keeping, and operating conditions should be described to show their adequacy

4. Proof of compliance with all applicable laws and regulations, state and federal, concerned with air pollution control

5. An indication that the emissions from the new source will be the minimum attainable using the best available control technology

The permit application for operation will need to address the following, in addition to the items addressed in the construction permit application:

1. Information for a total evaluation of the potential source 
2. Proof of compliance with the construction permit

The following are the emission limitations set by the Pennsylvania DER, Title 25 , Chapter 123.8 The particulate emission standard is specific to incinerators while the others are general maximum limitations not specific to any facility type.

1. Particulate emissions $\leqq 0.1$ grain/dry standard cubic foot corrected to 12 percent $\mathrm{CO}_{2}$

2. $\mathrm{SO}_{2}$ emissions $\leqq 500 \mathrm{ppm}$, by volume (dry basis)

3. Visible emissions $<20$ percent opacity for at least 57 minutes in any continuous 60-minute period, and at all times $<60$ percent opacity

Appropriate building permits from the Pennsylvania Department of Labor and Industry (DOLI) and Londonderry Township will also be required.

\section{Nuclear Regulatory Commission (NRC)}

10 CFR Párt 20, paragraph 20.305, Treatment or Disposal by Incineration, ${ }^{9}$ requires that the NRC approve the operation of the incinerator. In order to obtain this approval, a formal license amendment request to the NRC will be made in accordance with 10 CFR 50, paragraph 50.90, Application for Amendment of License or Construction Permit.

This application will include a Technical Evaluation Report (TER). The TER will serve as the safety analysis of the facility and will address the following areas:

1. Environmental releases to show compliance with 10 CFR Part 20, Appendix $B$ and 10 CFR Part 50, Appendix I

2. Test data to support release analysis 
3. Design of the incinerator system and test data to support capability of the system

4. Design of the facility, including interface with existing facilities on site

5. Monitoring provisions

6. ALARA considerations

7. Description of the operation of the system

8. Appropriate accident analyses

The NRC review of the TER will result in questions that will need to be answered by the applicant. Upon satisfactory responses to their questions, the NRC will issue a Safety Evaluation Report and grant approval for the operation of the facility.

At this time, it is not known if public hearings on the incinerator will be required. Since the Programmatic Environmental Impact Statement (see Reference 6) addresses an incinerator as part of the overall recovery effort, there are grounds for the NRC to rule that no public hearings will be required as long as the proposed facility is within the bounds specified in the-PEIS. However, it is likety that public hearings witl be conducted during the licensing of this facility.

It is not expected that a license application in accordance with 10 CFR Part 30, Rules of General Applicability to Domestic Licensing of By-product Material, will be required. This is primarily due to the facility being addressed in the PEIS. 
The major NRC requirements and guidelines applicable to the incinerator facility are:

1. 10 CFR Part 20, Standards for Protection Against Radiation establishes radiation limits for various areas of the facility

2. 10 CFR Part 50, Paragraph 50.34a, Design Objectives for Equipment to Control Releases of Radioactive Material in Effluents Nuclear Power Reactors - identifies information pertaining to equipment required to be included in applications

3. 10 CFR Part 50, Paragraph 50.36a, Technical Specifications on Effluents from Nuclear Power Reactors - establishes operating limits on effluents

4. 10 CFR Part 50, Appendix A, General Design Critiera for Nuclear Power Plants - identifies general requirements the facility must satisfy

5. 10 CFR Part 50, Appendix I, Numerical Guides for Design Objectives and Limiting Conditions for Operations to Meet the Criterion "As Low As Is Reasonably Achievable" for Radioactive Material in Light-Water-Cooled Nulcear Power Reactor Effluents establishes the environmental release limits which result in HEPA filters on the building exhaust

6. Regulatory Guide 1.21, Measuring, Evaluating, and Reporting Radioactivity in Solid Wastes and Releases of Radioactive Materials in Liquid and Gaseous Effluents from Light-WaterCooled Nuclear Power Plants - establishes need for effluent monitors

7. Regulatory Guide 1.143, Design Guidance for Radioactive Waste Management Systems, Structures, and Components Installed in Light-Water-Cooled Nuclear Power PJants - results in the 
building foundation being designed for the operating basis earthquake, and results in high level alarms in the TMI-2 main control room for each tank that contains radioactive liquid

8. Regulatory Guide 8.8, Information Relevant to Ensuring That Occupational Exposure at Nuclear Power Stations Wil1 Be As Low As Is Reasonably Achievable - provides information relevant to minimizing occupational radiation exposures

9. Branch Technical Position ASB 9.5-1, Guidelines for Fire Protection for Nuclear Power Plants - used to establish fire. protection requirements

\section{Environmental Protection Agency (EPA)}

There are no permits from EPA required for the facility primarily because of its size and the fact that the NRC will regulate it. The following EPA regulation, however, is applicable to the facility:

40 CFR Part 190, Uranium Fuel Cycle Standard, limits the total dose to any member of the general public from all sources of radiation from the fuel cycle to 25 mrem per year. 


\section{QUALITY ASSURANCE REQUIREMENTS}

Quality assurance requirements for design, procurement, fabrication, and construction of the incinerator facility will be based on the quality control provisions of applicable codes and standards, and the guidelines presented in NRC Regulatory Guide 1.143.

The quality assurance provisions outlined in Regulatory Guide 1.143 can be summarized as follows:

Design, procurement, fabrication, and construction activities shall conform to the quality control provisions of applicable codes and standards. In addition, or where not covered by the referenced codes and standards, the following quality assurance features shall be established:

\section{System Designer and Procurer}

a. Design and Procurement Document Control--Design and procurement documents shall be independently verified for conformance to established requirements by individual(s) within the design organization who are not the originators of the document. Changes to these documents shall be verified or controlled to maintain conformance to this standard.

b. Control of Purchased Material, Equipment, and Services-Measures shall be established to ensure that suppliers of material, equipment, and construction services are supplying these items to the quality specified in the procurement documents. This may be done by an evaluation or survey of the supplier's products and facilities.

c. Handling, Storage, and Shipping--Instructions shall be provided in procurement documents to control the handling, 
storage, shipping, and preservation of material and equipment to prevent damage, deterioration, and reduction of cleanliness.

\section{System Construction}

a. Inspection--In addition to required code instructions, a program for inspection of activities affecting quality shall be established and executed by or for the organization performing the activity to verify conformance with the documented instructions, procedures, and drawings for accomplishing the activity. This shall include the visual inspection of components, prior to the installation, for conformance with procurement documents, and the visual inspection of items and systems following installation, cleaning, and passivation (where applied).

b. Inspection, Test, and Operating Status--Measures shall be established to provide for the identification of items which have satisfactority passed required inspections and tests.

c. Identification and Corrective Action for Items of Nonconformance--Measures shall be established to identify items of nonconformance with regard to the requirements of the procurement. documents or applicable codes and standards, and to identify the remedial action taken to correct such items.

Regulatory Guide 1.143 also provides direction relative to specific code applications. These guidelines are presented in Table 4.

Other design, construction, and performance guidelines for operation of low level waste volume reduction processing systems have been proposed. One such standard is currently being developed by the ANS Standards Committee. ${ }^{10}$ Where practical, appropriate recommendations from applicable standards will be followed. 
TABLE 4. EQUIPMENT CODES

\begin{tabular}{|c|c|c|c|c|}
\hline Equipment & $\begin{array}{l}\text { Design and } \\
\text { Fabrication }\end{array}$ & $\underline{\text { Materials }}^{\mathrm{a}}$ & $\begin{array}{l}\text { Welder } \\
\text { Qual if ication } \\
\text { and Procedures } \\
\end{array}$ & $\begin{array}{l}\text { Inspection } \\
\text { and Testing }\end{array}$ \\
\hline Pressure vessels & $\begin{array}{l}\text { ASME Code } \\
\text { Section VIII, Div. } 1\end{array}$ & $\begin{array}{l}\text { ASME Code } \\
\text { Section II }\end{array}$ & $\begin{array}{l}\text { ASME Code } \\
\text { Section IX }\end{array}$ & $\begin{array}{l}\text { ASME Code } \\
\text { Section VIII, Div. } 1\end{array}$ \\
\hline Atmospheric tanks & $\begin{array}{l}\text { ASME Code } \\
\text { Section III, Class } 3 \text {, } \\
\text { or API } 650, \\
\text { or AWWA D-100 } \mathrm{C}\end{array}$ & $\begin{array}{l}\text { ASME Code } \\
\text { Section II }\end{array}$ & $\begin{array}{l}\text { ASME Code } \\
\text { Section IX }\end{array}$ & $\begin{array}{l}\text { ASME Code }{ }^{b} \\
\text { Section III; Class } 3 \text {, } \\
\text { or API } 650, \\
\text { or AWWA } D-100^{c}\end{array}$ \\
\hline 0-15 psig tanks & $\begin{array}{l}\text { ASME Code }{ }^{b} \\
\text { Section III, Class } 3 \text {, } \\
\text { or API } 620\end{array}$ & $\begin{array}{l}\text { ASME Code } \\
\text { Section II }\end{array}$ & $\begin{array}{l}\text { ASME Code } \\
\text { Section IX }\end{array}$ & $\begin{array}{l}\text { ASME Code } \\
\text { Section III, Class } 3 \text {, } \\
\text { or API } 620^{b}\end{array}$ \\
\hline Heat exchangers & $\begin{array}{l}\text { ASME Code } \\
\text { Section VIII, Div. } 1 \\
\text { and TEMA }\end{array}$ & $\begin{array}{l}\text { ASME Code } \\
\text { Section II }\end{array}$ & $\begin{array}{l}\text { ASME Code } \\
\text { Section IX }\end{array}$ & $\begin{array}{l}\text { ASME Code } \\
\text { Section VIII, Div. } 1\end{array}$ \\
\hline Piping and valves & ANSI B31.1 & $\begin{array}{l}\text { ASTM and ASME } \\
\text { Code Section II }\end{array}$ & $\begin{array}{l}\text { ASME Code } \\
\text { Section IX }\end{array}$ & ANSI B31. 1 \\
\hline Pumps & $\begin{array}{l}\text { Manufacturers' } \\
\text { standards }\end{array}$ & $\begin{array}{l}\text { ASME Code } \\
\text { Section II or } \\
\text { manufacturers' } \\
\text { standards }\end{array}$ & $\begin{array}{l}\text { ASME Code } \\
\text { Section IX } \\
\text { (as required) }\end{array}$ & $\begin{array}{l}\text { ASME Code } \\
\text { Section III, Class } 3 \\
\text { or Hydraulic Institute }\end{array}$ \\
\hline
\end{tabular}

'Manufacturers' material certificates of compliance with material specifications may be provided in lieu of certified material.

b ASME Code stamp, material traceability, and the quality assurance criteria of Appendix $B$ to 10 CFR Part 50 are not required. Therefore, these components are not classified as ASME Code Class 3.

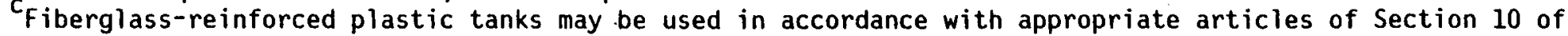
d the ASME Boiler and Pressure Vessel Code for applications at ambient temperature.

dManufacturers' standard for the intended service. Hydrotesting should be 1.5 times the design pressure. 


\section{SCHEDULE}

An engineering, procurement, and construction schedule for the CAI facility option without ash solidification (ash handling only) is presented in Figure 12. The total construction duration reflected is 14 months. The total duration from design start to facility availability is 35 months.

Although not included here, the engineering, procurement, and construction schedule for the CAI facility option with ash solidification contains the same logic and durations for all activities, except those associated with line 23 of the schedule. Duration for delivery of a solidification system (1ine 23) is approximately three months longer than that shown for the ash handling system. Nevertheless, the purchase and installation date for this system is early enough so that the critical path (discussed below) and overall schedule are not affected.

Key assumptions made in the development of this schedule include:

1. NRC approval of the Technical Evaluation Report (TER) is not required to start construction or testing.

2. The one year NRC review/approval period is only an assumption.

3. Review by other agencies (e.g., Department of Environmental Resources) is not controlling.

4. Estimates of delivery for incinerator process equipment are based on typical CAI offerings. Lead times for the ash handling (six months) and ash solidification (nine months) systems are based on data obtained from Teledyne Energy Systems. Construction durations for these items are estimates based on available system information; actual durations will depend on the systems procured. 


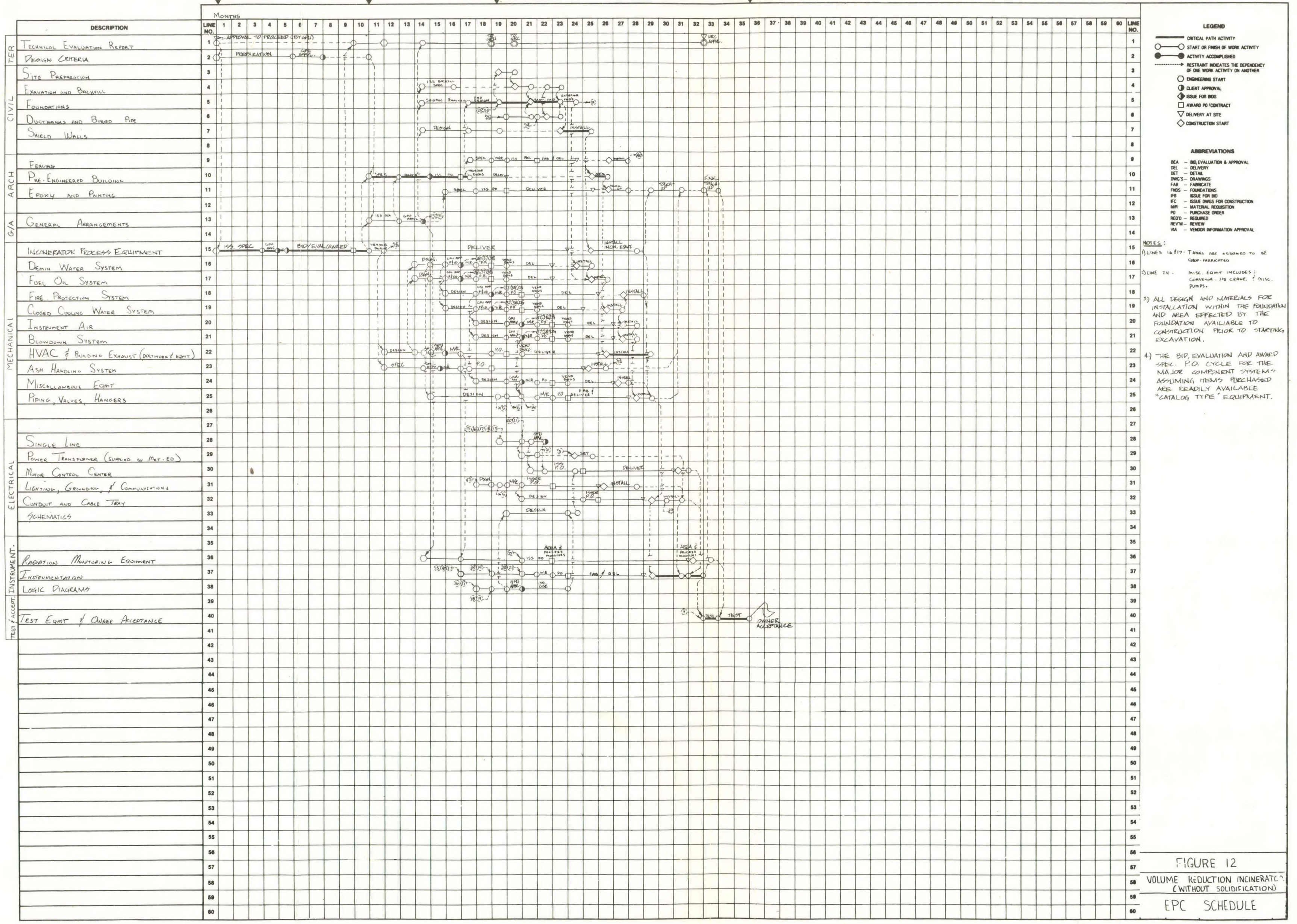


5. The power transformer is supplied by Met-Ed, and is currently available onsite.

6. The issue for bids, receive/evaluate bids, and award P.0. cycle for a majority of the components/systems (exclusive of the incinerator and ash handling/ash solidification) is accelerated. The accelerated schedule for these items assumes readily available, "catalog type" equipment.

7. Normal engineering, procurement, and construction activity time durations are assumed. DOE/EG\&G involvement is assumed to have no impact.

Critical path items include the following:

1. Incinerator process equipment (specification development and procurement (bid/eval/award))

2. Pre-engineered building (specification and drawing development, procurement (P.o. award), and installation)

3. Civil design and construction (foundation design and shield wall installation)

4. HVAC installation

5. Instrumentation installation

6. Final testing, checkout, and system turnover

Although not indicated on the schedule, because an incinerator facility has not been licensed previously, and because the time to do so is unknown, licensing may become a critical path item. 


\section{Cost Summary And Assumptions}

Tables 5 through 10 present costs for CAI facilities with provisions for either ash handling or ash solidification. Costs are based on two engineering start dates, November 1, 1981, and April 1, 1982. The latter date allows for contract negotiations between EG\&G/DOE and GPUSC, and provides more flexibility relative to cost assessment. Assumptions used in developing these estimates include the following:

1. Cost estimates for the incinerator are based on typical CAI offerings. Cost estimates for the ash handling and ash solidification systems are based on data obtained from Teledyne Energy Systems.

2. Costs associated with a six-month demonstration period, directly after Owner acceptance of the facility, have been included. These operating and maintenance costs are based on information provided to BNoC by GPU; this information is presented in Appendix B. Operating and maintenance costs after this initial demonstration period are not included.

3. Contingency is applied at 10 percent on BNoC services, GPU services, the incinerator, and ash handling/ash solidification equipment. Contingency is applied at 25 percent on the remainder of the mechanical equipment, all manual labor, civil, piping, electrical, and controls materials and subcontract work, and field nonmanual labor.

4. The estimates are given in escalated dollars. Escalation is applied at 10 percent per year to the center of each fiscal year. 
5. Cost estimates do not include any GPU surcharges for R\&Drelated contracting. Under the current contract provisions, these surcharges would apply to the controlled air incinerator.

The following equipment will be required for operation of the proposed incinerator facility. However, costs are not. included in this estimate.

1. 55-galion drums (for trash and ash transport)

2. Lead pig for radiation swipes

3. $50 \mathrm{ft}^{3}$ liners (for solidification)

4. Demineralized water and fuel oil trucks

5. Drum and liner transport trucks

6. Portable sump pump

7. Hand-held radiation counter (for personnel monitoring)

8. Cleanup materials (mops, buckets, etc.)

9. Blowdown disposal (if not solidified)

\section{Major Cost Uncertainties}

There are currently three major areas of uncertainty that may affect the overall cost estimates provided herein. These areas include the incinerator system, blowdown system, and chemical addition provisions.

1. As nuled in the Introduction, the conceptual design of the incinerator facility is based on space allocation and support services requirements for the installation and operation of a Helix CAI. Based on discussions with Helix and other CAI. 
suppliers and operators, there is reason to believe that there are still a significant number of unknowns relative to equipment supply and system function, operation, and performance of the beta-gamma CAI.

2. An estimate of wastes expected to be generated at TMI-2 during recovery operations showed that approximately 8.1 percent (by weight) of the wastes generated would be in the form of polyvinyl chloride (PVC) and rubber. Based on typical incinerator wet scrubbing systems and the expected TMI-2 generation rate of this waste, approximately 7,500 gallons of contaminated liquid blowdown per week would be generated. In order to reduce this blowdown to a quantity that could be solidified with cement, in. two $50 \mathrm{ft}^{3}$ liners per week, the amount of PVC and rubber would have to be limited to approximately 0.5 percent (by weight) of the total weekly waste quantity. If administrative controls could not be established to restrict the amount of PVC and rubber waste to approximately ${ }^{-} 0.5$ percent (by weight), added system costs would be incurred.

3. Associated with the burning of PVC and rubber with a wet off-gas system is the necessity of adding caustic solution. The caustic solution addition required $(0.25$ percent $\mathrm{NaOH})$ for 8. 1 percent (by weight) PVC and rubber waste incineration would be on the order of 750 gallons per week. By assuming restrictions on PVC and rubber burning at TMI-2, the caustic addition necessary is held to approximately 25 gallons per week, thereby reducing caustic solution preparation complexity and costs. Increases beyond this 25 gallon per week limit may involve the addition of more sophisticated caustic addition techniques. 
TABLE 5. CONTROLLED AIR INCINERATOR WITH SOLIDIFICATION PROJECT COST PERCENTAGES

Percent of Total

Bldg. Equip./Sys. Total Incinerator

Building Equipment/Systems

- Concrete

- Architectural and Other Civil

- Air Handiling

o Common Piping and Equipment

o Building Control System

- Lighting and Other Electrical

o Fire Protection System

Total

Incinerator Systems

- Materials Handling

- Helix Incinerator System

- Ash Handling or Sulidification

- Closed Cooling Water System

- Demineralized Water System

o Blowdown System

- Fuel 0il System

Total

Total Facility
27.0

16.0

11.0

2.0

7.0

33.0

4.0

100.0

33.0
2.0

42.0

20.0

1.0

1.0

0.5

0.5

67.0

100.0 
TABLE 6. CONTROLLED AIR INCINERATOR WITHOUT SOLIDIFICATION

PROJECT COST PERCENTAGES

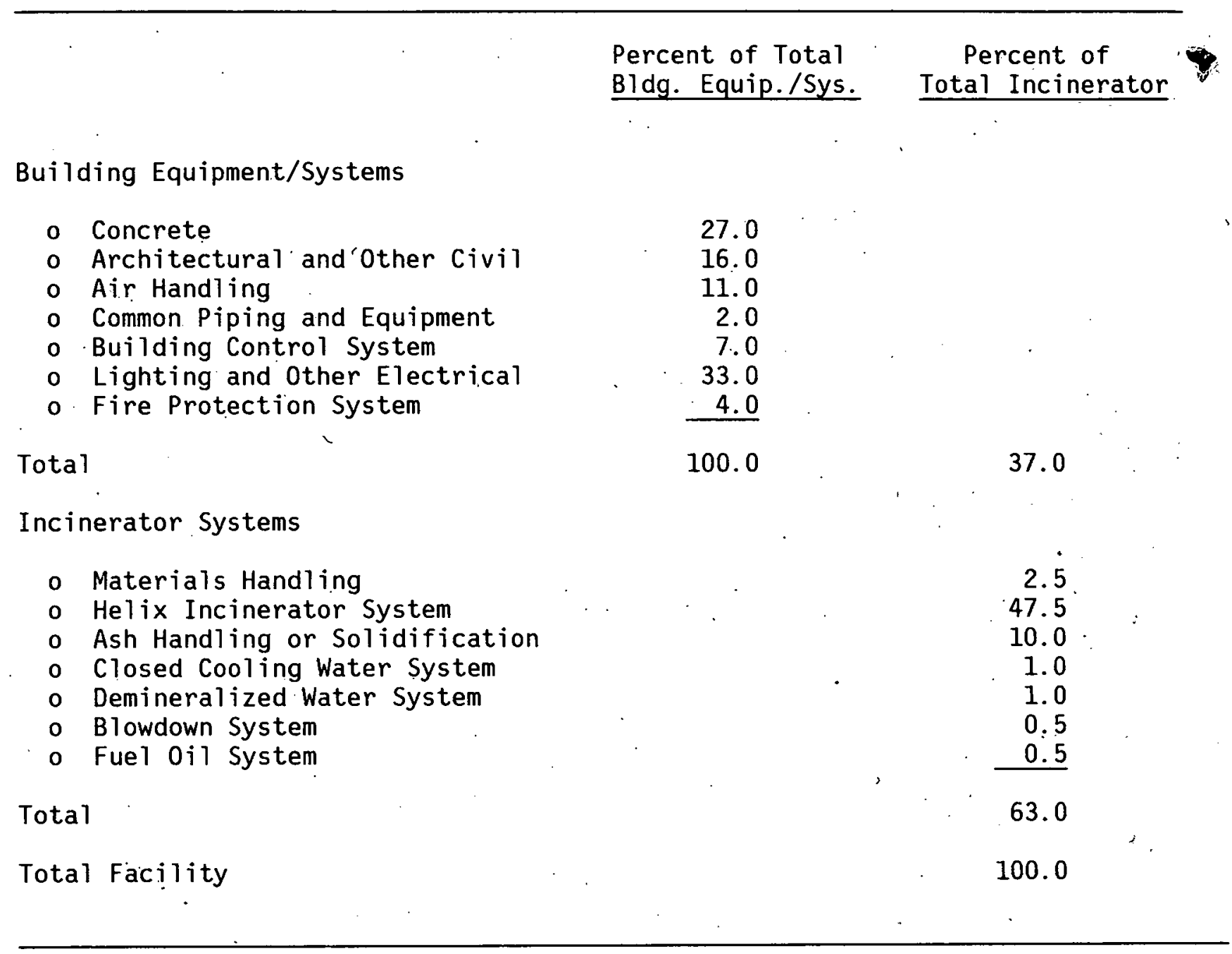


TABLE 7. SOLIDIFICATION - START ENGINEERING 11-1-81

(Dollars In Thousands)

\begin{tabular}{|c|c|c|c|c|c|}
\hline \multirow[b]{2}{*}{ Building } & \multirow[b]{2}{*}{$\underline{1982}$} & \multicolumn{3}{|c|}{ Fiscal Year } & \multirow[b]{2}{*}{ Total } \\
\hline & & $\underline{1983}$ & $\underline{1984}$ & $\underline{1985}$ & \\
\hline $\begin{array}{l}\text { Cash Flow } \\
\text { Commit }\end{array}$ & - & 630 & 570 & - & 1,200 \\
\hline \multicolumn{6}{|l|}{ Equipment } \\
\hline $\begin{array}{l}\text { Cash Flow } \\
\text { Commit }\end{array}$ & 2,000 & $\begin{array}{l}2,500 \\
1,200\end{array}$ & 1,585 & - & 4,145 \\
\hline \multicolumn{6}{|l|}{ Support } \\
\hline $\begin{array}{l}\text { A/E - Cash Flow HO } \\
\text { Constr. Mgmt., Cash Flow NM }\end{array}$ & $\begin{array}{r}740 \\
-\end{array}$ & $\begin{array}{r}1,180 \\
85\end{array}$ & $\begin{array}{l}460 \\
190\end{array}$ & - & $\begin{array}{r}2,380 \\
275\end{array}$ \\
\hline Subtotal & 740 & 4,455 & 2,805 & - & 8,000 \\
\hline Contingency on Above & 75 & 625 & 450 & - & 1,150 \\
\hline Subtotal & 815 & 5,080 & 3,255 & - & 9,150 \\
\hline Escalation on Above & 70 & 970 & 1,010 & - & 2,050 \\
\hline Subtotal & 885 & 6,050 & 4,265 & - & 11,200 \\
\hline Roundoff & 15 & $(50)$ & 35 & - & 0 \\
\hline Total Facility & 900 & 6,000 & 4,300 & - & 11,200 \\
\hline Owner Costs Prior to Acceptance & 135 & 220 & 640 & - & 995 \\
\hline Contingency & 15 & 20 & 65 & - & 100 \\
\hline Escalation & 15 & 45 & 220 & - & 280 \\
\hline Owner Subtotal & 165 & 285 & 925 & - & 1,375 \\
\hline Owner Costs During Demonstration & - & - & - & 760 & 760 \\
\hline Escalation & - & - & - & 315 & 315 \\
\hline Owner Total & 165 & 285 & 925 & 1,075 & 2,450 \\
\hline
\end{tabular}


TABLE 8. NON-SOLIDIFICATION - START ENGINEERING 11-1-81

(Dollars In Thousands)

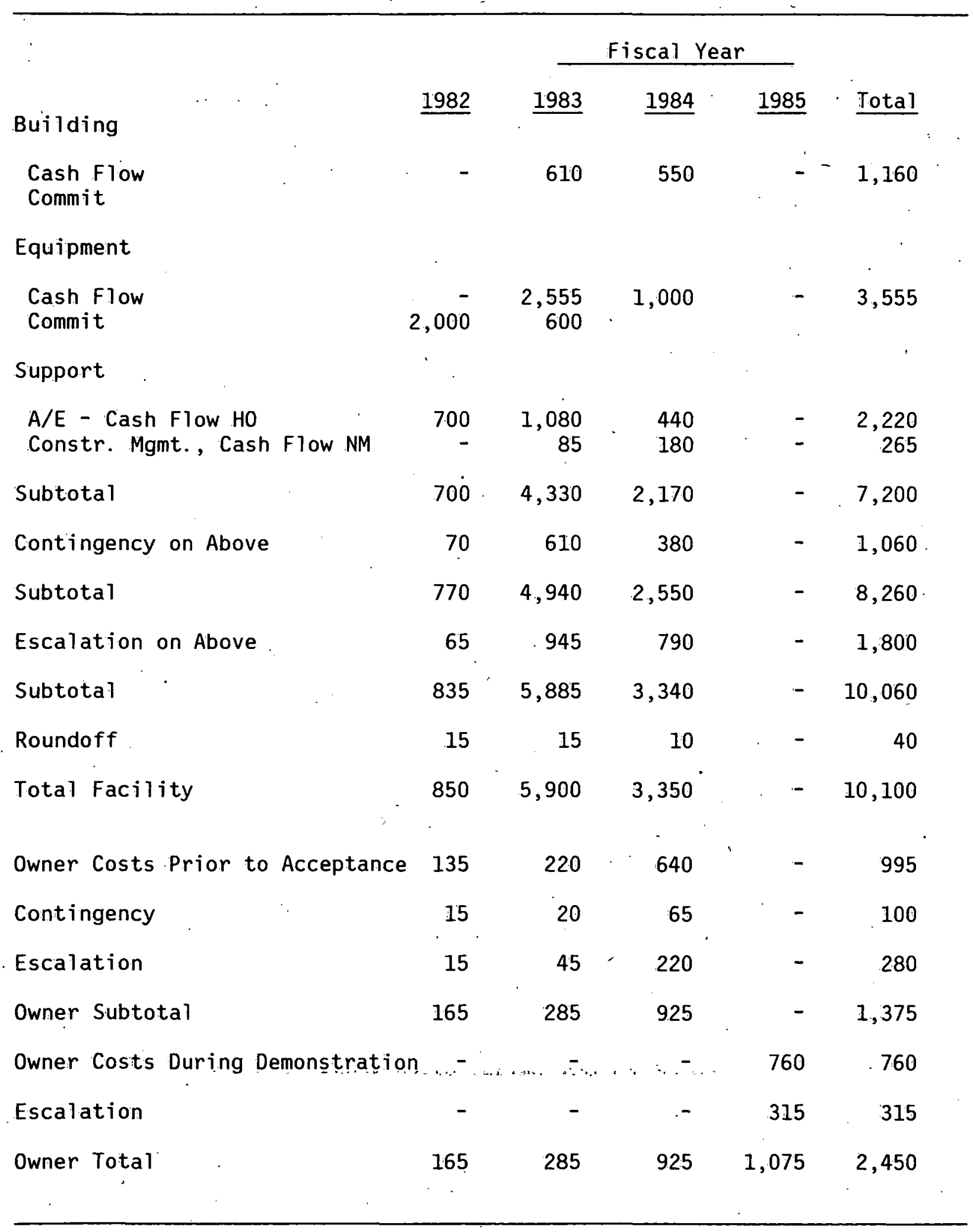


TABLE 9. SOLIDIFICATION - START ENGINEERING 4-1-82

(Dollars In Thousands)

\begin{tabular}{|c|c|c|c|c|c|}
\hline \multirow[b]{2}{*}{ Building } & \multirow[b]{2}{*}{$\underline{1982}$} & \multicolumn{3}{|c|}{ Fiscal Year } & \multirow[b]{2}{*}{ Total } \\
\hline & & 1983 & $\underline{1984}$ & 1985 & \\
\hline $\begin{array}{l}\text { Cash Flow } \\
\text { Commit }\end{array}$ & - & $\begin{array}{l}290 \\
110\end{array}$ & 800 & 110 & 1,200 \\
\hline \multicolumn{6}{|l|}{ Equipment } \\
\hline $\begin{array}{l}\text { Cash Flow } \\
\text { Commit }\end{array}$ & - & $\begin{array}{r}285 \\
2,000\end{array}$ & 3,800 & 60 & 4,145 \\
\hline \multicolumn{6}{|l|}{ Support } \\
\hline $\begin{array}{l}\text { A/E - Cash Flow HO } \\
\text { Constr. Mgmt., Cash Flow NM }\end{array}$ & $\begin{array}{r}420 \\
-\end{array}$ & $\begin{array}{r}1,280 \\
-\end{array}$ & $\begin{array}{l}570 \\
235\end{array}$ & $\begin{array}{r}110 \\
40\end{array}$ & $\begin{array}{r}2,380 \\
275\end{array}$ \\
\hline Subtotal & 420 & 1,855 & 5,405 & 320 & 8,000 \\
\hline Contingency on Above & 40 & 270 & 780 & 60 & 1,150 \\
\hline Subtotal & 460 & 2,125 & 6,185 & 380 & 9,150 \\
\hline Escalation on Above & 40 & 405 & 1,920 & 150 & 2,515 \\
\hline Subtotal & 500 & 2,530 & 8,105 & 530 & 11,665 \\
\hline Roundoff & - & 20 & (5) & 20 & 35 \\
\hline Total Facility & .500 & 2,550 & 8,100 & 550 & 11,700 \\
\hline Owner Costs Prior to Acceptance & 70 & 140 & 460 & 325 & 995 \\
\hline Contingency & 5 & 15 & 45 & 35 & 100 \\
\hline Escalation & 5 & 30 & 155 & 145 & 335 \\
\hline Owner Subtotal & 80 & 185 & 660 & 505 & 1,430 \\
\hline Owner Costs During Demonstration & - & - & - & 760 & 760 \\
\hline Escalation & - & - & - & 335 & 335 \\
\hline Owner Total & 80 & 185 & 660 & 1,600 & 2,525 \\
\hline
\end{tabular}


TABLE 10. NON-SOLIDIFICATION - START ENGINEERING 4-1-82

(Dollars In Thousands)

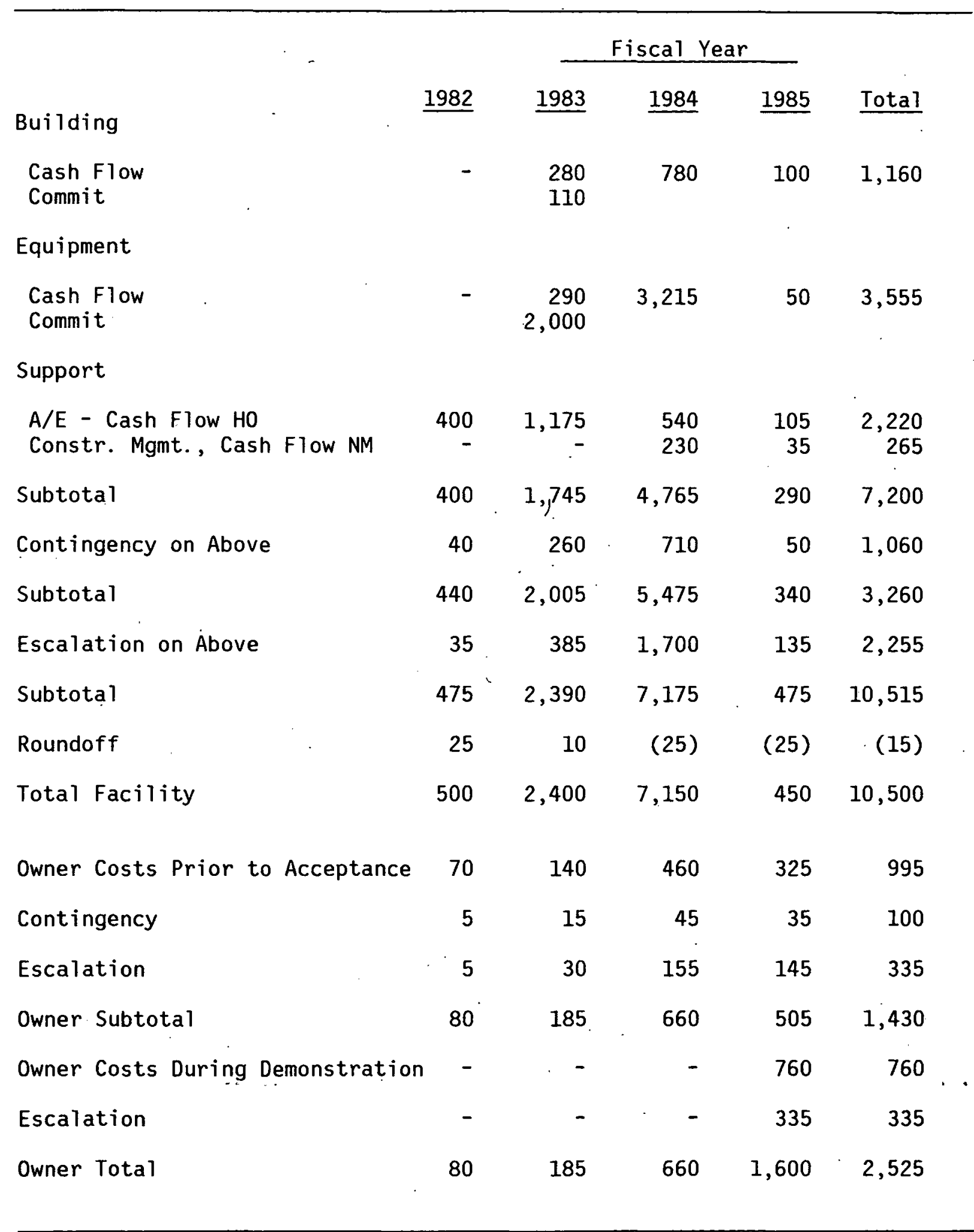


SUMMARY

\section{Potential Problems}

Although design and operational experience from several incinerator facilities has been considered in the preparation of this conceptual design, several areas are highly dependent on actual incinerator system selection and waste composition (type and form). The Helix Process Systems' Low Level Combustible Waste Incineration System has not yet been demonstrated. However, based on what is currently known about the Helix offering and TMI-2 wastes, the following considerations should be noted.

\section{Waste Form}

A large amount of waste that will be incinerated at TMI-2 will be compacted. Even though unloading of compacted waste from drums will result in some decompaction, the density of this waste is expected to be about 18.2 pounds per cubic foot, which is greater than that of noncompacted waste ( 8.5 pounds per cubic foot). ${ }^{a}$ This higher density waste will require a longer burning time and may present problems in obtaining complete combustion.

Regarding waste decompaction, the compacted drum unloading process proposed for the facility has not been tested with typical TMI-2 compacted waste. The process is based on standard industry practice for unloading compressed material. Unsatisfactory compacted drum unloading may require variation of this operation.

\section{Waste Type}

The estimate of the wastes expected to be generated at TMI-2 during recovery operations showed that approximately 8.1 percent (by weight) of the wastes generated would be in the form of polyvinyl chloride (PVC) and rubber. $b$ Based on typical incinerator wet scrubbing systems and the expected TMI-2

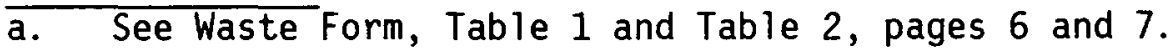

b. See Waste Form, Table 2, page 7 .
} 
generation rate of this waste, approximately 7,500 gallons of contaminated liquid blowdown per week would be generated. In order to reduce this blowdown to a quantity that could be solidified with cement in two $50 \mathrm{ft}^{3}$ liners per week, the amount of PVC and rubber would have to be limited to approximately 0.5 percent (by weight) of the total weekly waste quantity. If administrative controls could not be established to restrict the amount of PVC and rubber waste to approximately 0.5 percent (by weight), added system operating costs and possible corrosion problems will be incurred.

Associated with the burning of PVC and rubber with a wet off-gas system is the necessity of adding caustic solution. The caustic solution addition required $(0.25$ percent $\mathrm{NaOH})$ for 8.1 percent (by weight) PVC and rubber waste incineration would be on the order of 750 gallons per week. By assuming restrictions on PVC and rubber burning at TMI-2, the caustic addition necessary is held to approximately 25 gallons per week, thereby reducing caustic solution preparation complexity and costs. Increases beyond this 25 galion per week limit may involve the addition of more sophisticated caustic addition techniques.

\section{Incinerator System}

As previously noted, the conceptual design of the incinerator facility is based on space allocation and support services requirements for installation and operation of a Helix CAI. Based on discussions with Helix and other CAI suppliers and operators, there is reason to believe that there are still a significant number of unknowns relative to equipment supply and system function, operation, and performance of the beta-gamma CAI.

The actual expected life of the refractory material has not yet been established. One of the research and development aspects of an incinerator facility at TMI-2 would be the measurement of the degree to which radioactive material is retained in the refractory. It is probable, however, that the incinerator refractiory will not last for the design life of the incinerator facility (10 years). If replacement of the refractory requires removal of the incinerator from the building, extensive building disassembly (e.g., roof and roof support sections) and radiological controls will be required. 


\section{Recommendations}

As discussed previously in this report, incineration of PVC and rubber in the quantities expected for TMI-2 operations will result in large volumes of scrub solution blowdown which must be disposed of as liquid radwaste. Based on currently limited TMI-2 liquid radwaste processing capabilities and the uncertainty of future liquid radwaste processing plans, processing of large quantities of liquids from the incinerator is considered unacceptable. Blowdown solution could possibly be used for other solidification processes at TMI-2 besides ash solidification. However, alternate applications are presently undefined. The total volume reduction achieved with incineration of PVC and rubber is not expected to be as high as the condition where PVC and rubber is eliminated from the waste stream ${ }^{a}$; corrosion possibility is also minimized without the burning of PVC and rubber. It is therefore recommended that $P V C$ and rubber be administratively eliminated from the waste sent to the incinerator facility, and that other options for resolving this blowdown problem be investigated.

Use of a dry off-gas scrubbing system will eliminate the need for processing blowdown scrub solution. By this method, salts formed from the neutralization of burning PVC and rubber are collected in a dry. state, suitable for immediate solidification. At the Savannah River Laboratory (SRL) incinerator, where a dry off-gas system is planned, a volume reduction of 20:1 is anticipated, with a PVC and rubber content in excess of that expected at TMI-2. Consideration of a dry off-gas system is recommended to alleviate waste feed or blowdown 1 imitations at TMI- 2 .

The use of steam in the incinerator should be considered to promote carbon conversion from the waste ash and thereby increase volume reduction. Los Alamos Scientific Laboratory (LASL) presently uses about 15 pounds per hour of steam in their incinerator for this purpose, and SRL plans on using 10 to 15 pounds per hour of steam in their. incinerator. However, since there is presently no steam service near the proposed incinerator facility location, a local steam supply would have to be incorporated at the incinerator facility.

a. See Design Assessments, page 40 . 
The cost of a steam generator versus increased volume reduction should be the object of future study. (Note: Helix presently does not use steam in their incinerator.)

The following items are not included in the scope of this report. However, in order to optimize incinerator facility design, operation, and/or maintenance provisions, additional study is recommended:

1. Direct removal of heat generated by the incinerator via a shroud design instead of handling heat load by the HVAC

2. Installation of a heat recovery system to use heat generated from the incinerator for building heat, steam generation, etc.

3. Replacement of scrub solution filters with permanent backflushable filters

4. Disposal of blowdown solution if not used for solidification

5. Deletion of off-gas effluent opacity monitoring with HEPA filtration in favor of HEPA filtration (only)

6. Use of potable or well water in lieu of demineralized water for the incinerator and incinerator support systems

7. Investigation of 10 CFR 61 for ash solidification criteria and HIC applicability

8. Use of small HEPA filters in selected locations instead of one large HEPA filter for the whole building air flow

9. Consideration of additional sumps in the facility

10. Side-loading incinerator ram feeder versus top-loading design 
11. Alternative incinerator ram feeder quench options

12. Investigation of other solidification media besides cement

13. The possibility of locating the facility east of the Interim Solid Waste Staging Facility (ISWSF).

14. Reassessment of the 0.1 percent airborne radionuclide source term

15. Eliminating NRC Regulatory Guide 1.143, seismic applicability to the facility, or limiting application to scrubber system/ contaminated liquid system areas. 


\section{REFERENCES}

1. TMI Waste Storage Facilities Task Group, Chairman - R. L. Rider, Three Mile Island Radwaste Storage Facilities Task Group Report of Recommendations, December 1980.

2. J. C. Devine, letter to R. L. Rider, TMI-II-R-40185/TMI-BC-0137, Apri 1 22, 1981.

3. Bechtel Power Corporation, Three Mile Island, Unit 2, Planning Study for Containment Entry and Decontamination, July 2, 1979, Section 9.0.

4. Bechtel Northern Corporation, GPU Service Corporation Three Mile Island Unit 2 Recovery Facilities Project Design Criteria, Document No. 13587-2-G-100 (Rev. 0).

5. R. Lyman, letter to C. A. Negin, TMI-II-R-20906, May 21, 1981.

6. U.S. Nuclear Regulatory Commission, Final Programmatic Environmental Impact Statement, March 1981, Docket No. 50-320.

7. General Public Utilities Service Corporation, GPU Offsite Dose Calculation Manual, Three Mile Island Nuclear Generating Station, as corrected by BLGE-0169, dated December 4; 1980.

8. Pennsylvania Department of Environmental Resources, Title 25, Chapter 123, Standards for Contaminants.

9. Code of Federal Regulations, Title 10, Part 20, Paragraph 20.305, "Treatment or Disposal by Incineration."

10. American National Standards Committee Work Group ANS 40:35, Draft Proposed American National Standard 40.35, "Volume Reduction of Low Level Radioactive Waste," Draft 1, Revision 4, March 1981. 
APPENDIX A

\section{INCINERATOR FACILITY CRITERIA}

The conceptually designed controlled air incinerator (CAI) facility described in the text of this report is based on the following criteria; these criteria are compatible with most aspects of the Los Alamos Scientific Laboratory (LASL) incinerator design, except in the area of scrub solution blowdown: ${ }^{a}$

\section{Purpose}

The purpose of the incinerator facility is to demonstrate the controlled air incineration process developed at Los Alamos Scientific Laboratory as a viable method for low-level radioactive waste incineration at a commercial nuclear facility. The incinerator facility will be temporary with a proposed lifetime of 10 years:

\section{Function}

The function of the incinerator facility is to reduce, by incineration; the large volume of low-level combustible radwaste expected to be generated from cleanup and normal operations at TMI-2. The incinerator facility will either have provisions for solidification of the ash at the facility, or have provisions for packaging the ash for transport to an undefined location.

\section{Interfaces With TMI Services}

The incinerator facility will interface with the following existing plant systems:

\subsection{Demineralized Water System}

Demineralized water will be obtained from the existing plant demineralized water system to supply all water needs of the incinerator facility. Water

a. See Experience From Existing Controlled Air Incinerators, page 37. 
will be transported by tank truck to an outside storage tank located adjacent to the incinerator facility.

\subsection{Fire Protection}

Alarms from the building fire detection system will interface with the existing plant fire detection system in the Unit 2 main control room. Fire water will be provided via a tie-in to the existing plant system.

\subsection{Communication System}

The building communication system will interface with the existing plant public address system to provide coordinated activity between the incinerator facility and the remainder of the plant. Raceways will be provided to permit extension of the telephone system into the incinerator facility office area.

\subsection{Ash and Solidified Ash Removal}

Ash drums from the incinerator facility will either be transported directly to a solidification facility or staged in a solid waste staging module. Solidified liners will be staged in a solid waste staging module.

\subsection{Monitors and Process Alarms}

The effluent radiation monitors will. interface with the existing plant monitoring system. The off-gas opacity monitor will interface with the plant computer. Tanks in the incinerator facility which contain radioactive iquids will be provided with the high-level alarms in the TMI-2 main control room.

\subsection{Electrical}

The incinerator facility will interface with the existing electrical system to provide power for heating, lighting, mechanical equipment, and instrumentation. 


\section{Functional Requirements}

\subsection{Function of the Facility}

The incinerator facility shall be designed for occupancy by workers on a daily basis and shall be provided with radiation protection features adequate to minimize radiation dose to operating personnel. The facility shall provide all support requirements for the incineration of combustible lowlevel radwaste.

\subsection{Function of the Equipment}

4.2.1 Incinerator. The incinerator shall be capable of burning waste 24 hours per day, 5 days per week, and shall consume at least 3,275 pounds. of waste in that time period. Wastes loaded into the incinerator must be packaged in polyethylene bags, cardboard boxes, or other consumable packages. Dimensions of these waste packages will be limited to approximate dimensions of the metal screening device $\left(20^{\prime \prime} \times 27^{\prime \prime}\right)$, or the dimensions of the incinerator ram feeder $\left(42^{\prime \prime} \times 32^{\prime \prime} \times 36^{\prime \prime}\right)$ if metal screening is not required.

4.2.2 Sampling. Sampling equipment shall be capable of taking radiation swipes of filled liners or drums prior to transport from the incinerator facility. Off-gas emissions to the environment will be monitored as required by applicable Federal and State regulations.

\subsubsection{Precombustion Waste Handling. Prior to incineration, a scale shall} weigh the waste to determine density, an x-ray machine will survey the waste for large metal or other noncombustible objects, and a glove box shall be capable of allowing removal of any of these large objects found. Two drum dumpers will be able to unload either compacted or noncompacted waste. No screening for PVC or rubber will be performed in the waste handling area. Shielded forklifts shall be available to move waste drums into the building, and to the storage and drum unloading areas. The waste handling equipment design will be such that minimal lifting by personnel is required, and a high volume throughput of waste for incineration is achieved. 
4.2.4 Waste Disposal and Processing. For the facility design without ash solidification provisions, ash handling equipment will remotely transfer the ash from the waste ash hopper into 55-gallon drums, cap the drums, and transfer the drums to a shielded forklift for removal from the building. The facility design with ash solidification provisions will have a space allowance for equipment to solidify and remove solidified ash containers (1iners) from the building. To handle scrub solution blowdown, a pump shall transfer blowdown to either an outside connection or to the ash solidification area.

\subsection{Facility Availability}

The incinerator facility will be designed as a demonstration facility for the development of low-level radioactive waste incineration. No special provisions for availability and reliability, beyond that afforded by good engineering and operating practice, will be provided.

\subsection{Accessibility}

The incinerator facility shall be enclosed by a security fence with a motorized gate. Building ingress and egress shall be controlled in accordance with health physics procedures. Fire exits will be provided as required by the Pennsylvania Code for Fire and Panic Regulations, the Department of Labor and Industry, and OSHA requirements. Within the building, access space shall be allowed for equipment maintenance and handling of contaminated equipment and tools. The layout of the facility shall take into consideration ease of movement of equipment and personnel.

\subsection{Maintainability}

The incinerator facility floor and other surfaces that may require decontamination shall be painted and sealed with epoxy. Capabilities for isolating equipment that requires frequent maintenance'shall be provided. In addition; provisions for flushing radioactively contaminated systems shall also be provided. 


\subsection{Safety}

The incinerator facility shall comply with the occupational exposure limits of 10 CFR 20 and the guidelines of NRC Regulatory Guide 8.8. Areas shall be zoned according to radiation fields. Signs and markings shall be posted to flag exits, fire protection equipment, radiation zones, and safety equipment. Radiation areas shall be zoned according to the radiation levels set forth in the General Project Design Criteria (13587-2-G01-100). ${ }^{1}$ The facility will be provided with an emergency shower, an eyewash fountain, and a first aid box. Protective clothing shall be provided as needed. A health physics control point shall be provided at the point of entry to working areas from the office/personnel change area. The atmosphere inside the waste preparation glove box will be maintained at a negative pressure of $\frac{1}{4}$ to $\frac{1}{2}$ inch of $\mathrm{H}_{2} \mathrm{O}$ with respect to the facility during use. A sump will be provided to collect radioactive liquid spills or leaks.

\subsection{Personnel}

At any given time, a maximum of five operating personnel will be needed for normal facility operation.

\section{Design Requirements}

\subsection{General Requirements}

The facility design shall be based upon the BOCA Basic Building Code. The facility shall be designed for minimal generation of radioactive waste and for easy decontamination of the floors.

\subsection{Safety Design Bases}

This facility has no safety-related function and, therefore, no safety design bases. 
5.3 Codes, Standards, and Regulatory Requirements

The incinerator facility design, construction, and operation shall meet the following codes, standards, and regulatory requirements, as applicable:

\subsubsection{Federal.}

1. 10 CFR Part 20 - Standards for Protection Against Radiation

2. 10 CFR Part 50, Appendix A - General Design Criteria for Nuclear Power Plants

3. 10 CFR Part 50, Appendix I - Numerical Guides for Design Objectives and Limiting Conditions for Operations to Meet the Criterion "As Low As Is Reasonably Achievable" for Radioactive Material in Light-Water-Cooled Nuclear Power Reactor Effluents

4. 29 CFR Part 1910 - Occupational Safety and Health Standards

5. 40 CFR Part 190 - Uranium Fuel Cycle Standard

6. Occupational Safety and Health Administration (OSHA)

\subsubsection{Industry.}

1. American National Standards Institute (ANSI)

2. American Society for Testing and Materials (ASTM)

3. Building Official and Code Administrators (BOCA)

4. American Institute of Steel Construction (AISC)

5. National Concrete Masonry Association

6. Underwriters Laboratories Inc. (UL) 
7. Factory Mutual Engineering Corporation (FM)

8. American Iron and Steel Institute (AISI)

9. Insulated Cable Engineers Association (ICEA)

10. National Electrical Manufacturers Association (NEMA)

11. Institute of Electrical and Electronics Engineers (IEEE)

12. National Fire Protection Association (NFPA)

\section{3 .3 USNRC.}

1. Regulatory Guide 1.21 - Measuring, Evaluating, and Reporting Radioactivity in Solid Wastes and Releases of Radioactive Materials in Liquids and Gaseous Effluents from Light-WaterCooled Nuclear Power Plants

2. Regulatory Guide 1.60 - Design Response Spectra. for Seismic Design of Nuclear Power Plants

3. Regulatory Guide 1.61 - Damping Values for Seismic Design of Nuclear Power Plants

4. Regulatory Guide 1.92 - Combining Modal Responses and Spatial Components in Seismic Response Analysis

5. Regulatory Guide 1.140 - Design, Testing, and Maintenance Criteria for Normal Ventilation Exhaust System Air Filtration and Adsorption Units of Light-Water-Cooled Nuclear Power Plants

6. Regulatory Guide 1.143 - Design Guidance for Radioactive Waste Management Systems, Structures, and Components Installed in Light-Water-Cooled Nuclear Power Plants 
7. Regulatory Guide 8.8 - Information Relevant to Ensuring That Occupational Radiation Exposures at Nuclear Power Plants Will Be As Low As Is Reasonably Achievable

8. Branch Technical Position ASB 9.5-1 - Guidelines for Fire Protection for Nuclear Power Plants

\section{3 .4 State.}

Pennsylvania Department of Environmental Resources (DER), Title 25, Chapter 123, Standards for Contaminants

\subsection{Environmental Design Bases}

Normai releases of radioactive material to the environment from the facility will be limited such that the resultant dose to the public will be a small fraction of that allowed by 10 CFR Part 50, Appendix I.

The incinerator will meet the following. emission limits as set forth in the Pennsylvania DER, Title 25, Chapter 123:

1. Particulate emissions $\leqq 0.1$ grain per dry standard cubic foot, corrected to 12 percent $\mathrm{CO}_{2}$.

2. $\mathrm{SO}_{2}$ emissions $\leqq 500 \mathrm{ppm}$, by volume (dry basis).

3. Visible emissions $<20$ percent opacity for at least 57 minutes in any continuous 60-minute period, and at all times $<60$ percent opacity. To ensure compliance, an opacity monitor will be provided to monitor the off-gas effluent.

\subsection{Radiation Shielding Requirements}

Radiation shielding-will be provided in order to limit the dose rates as foll lows:

1. Change Area and Office $\leqq 0.5 \mathrm{mrem} / \mathrm{hr}$ 
2. Control. Panel/Metal Screening Area $\leqq 2.5 \mathrm{mrem} / \mathrm{hr}$

3. Personnel Monitoring/Step-0ff Pad Area $\leqq 0.1 \mathrm{mrem} / \mathrm{hr}$

4. Work Area Outside Solidification/Ash Storage $\leqq 2.5 \mathrm{mrem} / \mathrm{hr}$

5. Offsite dose $\leqq 25 \mathrm{mrem} /$ year from the site

\subsection{Layout Requirements}

The layout of the incinerator facility will encompass a waste receiving area, an incineration process area, an ash handling area, and an area for all necessary support services required for incinerator operation and maintenance, taking into account "As Low As Is Reasonably Achievable" (ALARA) considerations. The facility will be located so as to allow tank truck access. A change area and office will be provided in the building for administrative activities and changing of anticontamination clothing. A fence will enclose the incinerator facility for security purposes.

\subsection{Materials of Construction}

5.7.1 Facility Materials. The building housing the incinerator shall be a pre-engineered, rigid frame metal building. The building will be designed for the basic wind and snow loads specified in the TMI Civil Structural Design Criteria. The building will be designed for minimum seismic loads as determined by the BOCA Building Code, and will be seismically checked in accordance with NRC Regulatory Guide 1.143. The foundation will be reinforced concrete and of a combined mat design. A 4-inch curb shall be provided to contain any fire water released within the building. The construction joint between the curb and slab shall contain a water stop. All shield walls inside the facility will be reinforced concrete. A loading dock will. be provided outside the building with details similar to those of the main building.

5.7.2 Incinerator Systems Equipment. All materials for the service support systems and interconnecting piping for the incinerator shall be compatible with the fluids which they handle. 


\subsection{Painting and Coating Requirements}

All floors and walls, except those in the load center room and HVAC equipment room, shall be sealed with epoxy up to the curb height. The following areas shall have the full height of the walls coated with epoxy to allow for decontamination:

\section{Trash Storage}

\section{Incinerator}

3. Scrub Solution

4. Ash Handling

The epoxy coating shall have a Class I surface burning characteristic ( 0 to 25 when tested to ASTM E 84). All doors and frames shall receive manufacturer's standard primer and field applied finish coating.

\subsection{Electrical Requirements}

5.9.1 Power. Electrical power for the incineration facility will be provided from an existing 13.2-kV overhead line via a $13.2 \mathrm{kV}$ to $480 \mathrm{~V}, 3$ phase, pad-mounted transformer adjacent to the incinerator building. Power from the transformer to the incinerator service entrance equipment will be via underground ducts. In addition, a second source of 480 volt power will be provided for redundant service to the induced draft fans (two), and the scrub solution recirculation and transfer pumps (four). A motor control center (MCC) with a required service entrance disconnect switch will be provided to supply all facility electrical loads. A section of the MCC will service redundant loads and will be connected to the main MCC section with an automatic transfer switch. All electrical loads will normally be supplied from the $13.2-k V$ overhead 1 ine.

5.9.2 Lighting. The normal lighting system for the incinerator facility will provide adequate illumination levels and convenience power for operating and service conditions. In addition, it serves as a distribution system for 
miscellaneous small load requirements. This system consists of a complete distribution network of cables, raceways, transformers, lighting panels, lighting fixtures, receptacles, and switches. Lighting levels will be 20 fc in mechanical equipment room areas, $30 \mathrm{fc}$ in process areas, and $100 \mathrm{fc}$ in the office area. Exterior lighting levels will be in accordance with existing site surveillance requirements.

An emergency lighting system will provide emergency lighting for egress routes and will consist of individual, self-contained, sealed-beam battery units (8-hour rated). These battery units are connected to the normal ac source to maintain battery charge, and automatically transfer to their internal batteries upon loss of ac power. Illumination levels will be as required by the Pennsylvania Department of Labor and Industry Fire and Panic Regulations.

5.9.3 Cable. Power and control instrument cable will meet IEEE 383 flame resistance tests. Capacity rating and group derating factors of cables will be in accordance with ICEA P-46-426 for cables in conduit, ducts, and trays with maintained spacing. ICEA P-54-440 will be used for cables in random filled trays.

Single phase branch circuit wiring for receptacle and lighting runs will be copper with insulation rated for $75 \mathrm{C}, 12$ AWG minimum gauge. Insulation will be 600 volt, type THW, moisture and heat resistant thermoplastic. Lighting fixture wire shall be Class $B$ stranded, tinned copper with insulation rated for $200 \mathrm{C}, 14$ AWG minimum gauge. Insulation will be 600 volt, type SF-2 silicone rubber.

Polyvinyl chloride (PVC) insulation will not be used in any cable construction with the exception of lighting and receptacle wiring, which will be totally enclosed in conduit. All lighting and receptacle wire shall carry Underwriters Laboratories approval. 


\subsection{Mechanical Requirements}

5.10.1 General. The facility shall be designed without floor drains. Any water that may spill on the floor will be contained by the building curb, and will be removed by mops or wet vacuum cleaners that will transfer water from the floor to portable containers. A sump will be provided in the scrub solution area to collect leakage or overflow from the scrub solution or blowdown tank. Any water collected in the sump will be transferred to portable drums or other suitable containers by using a portable sump pump.

5.10.2 Waste Receiving. Waste shall be brought to the incinerator facility in 55-gallon drums. Drums of noncompacted waste will be packaged in doubled plastic bags; waste compacted in drums will not be bagged. The incinerator facility will be capable of receiving and storing one day's worth of drums filled with waste. The waste will be unloaded, weighed, and surveyed for metal or other large noncombustible objects prior to incineration. There will be no provisions to assay the waste for radionuclide content at the incinerator facility. Empty drums will not be decontaminated prior to removal from the facility.

5.10.3 Waste Incineration. Waste shall be fed to the incinerator at the rate of 350 pounds per hour (maximum). Provisions shall be made for the incineration of waste $0 i 1$ and resins.

5.10.4 Ash Handling. Ash will be transferred from the incinerator chamber to an ash hopper located in the ash packaging/ash solidification area. The ash in this hopper shall be remotely loaded into containers for transport from the facility.

5.10.5 Scrub Solution Disposal. Provisions shall be made for the transfer of blowdown scrub solution from the blowdown storage tank to either the facility solidification area (if available), or to a location outside the building for transfer to a liquid radwaste system.

5.10.6 Ash Solidification. A space allowance for a remotely operated ash solidification system shall be provided for the facility design with ash solidification provisions. 
5.10.7 Fire Protection Requirements. An early warning fire detection system consisting of ionization and rate-compensating fire/smoke detectors shall alarm locally and in the TMI-2 main control room. Principal facility fire protection shall be provided by a wet pipe, fused head sprinkler system in accordance with NFPA 13. Backup fire suppression capability will be available from portable fire extinguishers in accordance with NFPA 10, from hose reels in accordance with NFPA 14, and from fire hydrants located outside the building in accordance with NFPA 24. Fire walls and barriers will be provided as required by the Pennsylvania Code, Fire and Panic Regulations.

5.10.8 Heating, Ventilating, and Air-Conditioning (HVAC) Requirements. The HVAC system will provide an environment suitable for personnel comfort and equipment performance. The following maximum and minimum temperatures shall be maintained (max. summer, min. winter):

1. Incinerator area: $120 \mathrm{~F}$ summer, $50 \mathrm{~F}$ winter

2. Support service equipment area: $104 \mathrm{~F}$ summer, $50 \mathrm{~F}$ winter

3. Waste handling area: $85 \mathrm{~F}$ summer, $50 \mathrm{~F}$ winter

4. Office: $78 \mathrm{~F}$ summer, $68 \mathrm{~F}$ winter (nominal)

The system shall exhaust more air from the bujlding than the outside supply air to the building. Outside supply air shall be filtered and heated (when required) before being supplied to the building by a sheet metal duct system. Exhaust air from the building shall be filtered by high efficiency particulate air (HEPA) filters to remove contaminated particles before being exhausted to the outside. Exhaust air from the building shall be monitored for airborne particulate radioactivity. Exhaust air ports from the waste sorting glove box shall be ducted to an exhaust air header which will be connected to the building exhaust air duct. An isolation damper shall be provided in this exhaust air header so that in the event the radiation leve 1 in the glove box becomes unacceptable, it can be isolated by manually closing the isolation damper. Within the incinerator facility, the building air flow shall be maintained from areas of lower radiation level to areas of higher radiation lever. 


\subsubsection{Support Services.}

5.10.9.1 Service Air System--The service air system will provide a continuous supply of air for process instrumentation, shutdown, and ash transfer needs, and for building HVAC instrumentation needs. The system shall be capable of providing $20 \mathrm{scfm}, 100 \mathrm{psig}$, of dry and oil free air. An air receiver shall be provided to ensure safe, orderly shutdown.

\subsubsection{Demineralized Water System--The demineralized water system shall} supply all water service needs of the incinerator facility. The system shall provide continuous makeup water to the scrub solution tank, and shall supply fill and/or flush water for the emergency fill tank, caustic addition tank, liner or drum wash station (only in ash handling or solidification area), closed cooling water compression tank, blowdown tank and blowdown process line, incinerator ram feeder, solidification (if applicable), and miscellaneous service connections. The source of demineralized water shall be from a storage tank located adjacent to the incinerator building, sized to approximately one week's worth of water; the tank shall be refilled by a tank truck.

5.10.9.3 Cooling Water System--The cooling water system shall supply cooling water tc the incinerator scrub solution cooler and wet off-gas condenser. The system shall be capable of delivering $180 \mathrm{gpm}$ at a minimum pressure of 25 psig and a maximum temperature of $110 \mathrm{~F}$. The cooling loop will be closed in order to prevent direct releases of radioactive scrub solution leaks to the environment.

5.10.9.4 Fuel 0il System--The fuel oil system shall supply a 3 psig supply of fuel oil to the incinerator. The fuel oil source shall be from a storage tank located outside the building sized to hold approximately one week's worth of fuel oil. The fuel oil tank shall be surrounded by a fire wall on the three sides closest to the incinerator building. 


\subsection{Instrumentation and Control Requirements}

\subsubsection{Process.}

5.11.1.1 Instrument Air--Controls for operation of the instrument air system will be provided on the compressor skid. An alarm for low air pressure will be provided on the incinerator control panel.

\subsubsection{Demineralization (Makeup) Water--Level indication, temperature} indication, and low-level alarm for the demineralized water storage tank, and control for the demineralized water transfer pump, will be provided on the incinerator control panel. Thermostat control will be provided for the tank immersion heater.

5.11.1.3 Cooling Water--Local controls and instrumentation will be provided for the cooling water system. A trouble alarm will be provided on the incinerator control panel.

5.11.1.4 Fuel 0il--Level indication and low-level alarm for the fuel oil storage tank, and control for the fuel oil pump, will be provided on the incinerator control panel. Thermostat control will be provided by the fuel oil line heat tracing.

5.11.1.5 Scrub Solution System--High-level alarms. will be provided in the TMI-2 main control room for the scrub solution tank and the blowdown tank.

5.11.1.6 Waste $0 i 1$ and Blowdown Pumps--Local controls will be provided for the operation of these pumps.

\subsubsection{Facility.}

5.11.2.1 HVAC--Local controls and instrumentation will be provided for the HVAC supply and exhaust system. Indication and alarms will be provided on the incinerator control panel for the exhaust filtration system differential pressure and flow. 
5.11.2.2 Fire Protection--Local-fire alarms and an alarm in the TMI-2 main control room will be provided.

\subsection{Radiation Monitoring}

Radiation monitoring will be supplied for area radiation process monitoring, and effluent monitoring. Area radiation monitors will be in the following locations:

1. Near the office, at the waste entrance and exit point

2. Control panel area (common to the incinerator loading and waste sorting area)

3. In the passageway to the support services area (near the ash handling/solidification area)

Process monitors will be located on each scrub solution filter and the scrub solution blowdown tank to determine the need for changeout of the filters and to monitor bulk radioactivity of the scrub solution. Effluent monitors will be located at the facility HVAC release point and the off-gas release point; there will be two monitors at the off-gas release point. The area radiation monitors and the process monitors will alarm at the incinerator control pane1. The effluent monitors will alarm at the incinerator control panel and in the Unit 2 main control room. The effluent monitors will be continuously recorded.

\subsection{Interlocks and Administrative Controls}

PVC and rubber content of the incinerator waste feed shall be administratively controlled at the point of waste generation such that the blowdown necessary from the scrub solution is limited to 375 gallons per week. The HVAC system shall shut down whenever a fire or smoke detector is activated. A remote alarm shall be provided at the TMI-2 main control, room to indicate a fire in the incinerator facility. 


\subsection{Communications}

Communications will be provided by equipment ties into the plant public address system, and by an intercom for internal communications only. Telephone service will be provided in the office.

\section{References}

The following was used in the preparation of these design criteria.

1. Bechtel Northern Corporation, GPU Service Corporation Three Mile Island Unit 2 Recovery Facilities Project Design Criteria, Document No. 13587-2-G-100 (Rev. 0). 
APPENDIX B

GPU COST INFORMATION ${ }^{\mathrm{a}}$

GPU COSTS AND O\&M COSTS FOR INCINERATOR STUDY

\section{Prior to Owner Acceptance}

1. GPU management $\$ 415,000$

$\$ 11,530 /$ month for 36 months

2. Technical support prior to operations

$\$ 320,000$

$\$ 26,700 /$ month for 12 months

3. Technical support during startup testing $\$ 100,000$

$\$ 33,330 /$ month for 3 months

4. $0 \& M$ during startup testing $\$ 160,000$

$\$ 53,330 /$ month for 3 months

Demonstration Period (Assumed to be distributed evenly 6 months after startup testing)

1. Modification resulting from startup

testing and demonstration

$\$ 300,000$

2. Technical support

$\$ 80,000$

3. Documentation of startup and demonstration

$\$ 80,000$

4. $0 \& M$

$\$ 300,000$

a. Taken from GPU letter TMI-II-R-4300-81-181, dated June 26, 1981. 
BACKUP FOR GPU COSTS

\section{Prior to Owner Acceptance}

1. Management

Project Manager Project Engineer Operations Reviews Consultant Reviews

$1 \frac{1}{2}$ man-year/year

$3000 \mathrm{hrs} / \mathrm{yr} \times 3$ years $\times \$ 35 / \mathrm{hr}=\$ 315,000$

Licensing Management $\quad 1000 \mathrm{hrs} \times \$ 40 / \mathrm{hr}=\$ 40,000$

QA Management and Procedure Review $1500 \mathrm{hrs} \times \$ 40 / \mathrm{hr}$

$=\$ 60,000$

$\$ 415,000 / 36$ months $=\$ 11,530 /$ month $\$ 415,000$

2. Technical Support Prior to Operations

Startup Program, Write, Review, Approve

Startup Scope, Specs, Procedures

(Approximately 20)

Operation Procedures, Write, Review, Approve Technical Specifications for Facility

Training Program

Assume Four Engineers Full Time for 1 year

$8000 \mathrm{hrs} \times \$ 40 / \mathrm{hr}$

$\$ 320,000$

3. Technical Support During Startup Testing

Assume Five Engineers Full Time for 3 Months Executing and Observing Procedures

$$
2500 \mathrm{hrs} \times \$ 40 / \mathrm{hr}
$$

4. Operating and Maintenance During Startup Testing

Assume that Normal Operation Requires Three

Persons, Add One Extra During Startup

Also Assign Three Persons Half Time to Cover Instrument Calibration, Control System Tuning, Electrical Maintenance, Mechanical Mainteriance, Health Physics, Waste Delivery, etc.

Four Operators $\times 24 \frac{\mathrm{hrs}}{\mathrm{day}} \times 5 \frac{\text { days }}{\mathrm{wk}} \times 13 \mathrm{wks} \times \frac{\$ 20}{\mathrm{hr}}=124,800$ 
Three Miscellaneous $\times 12 \cdot \frac{\mathrm{hrs}}{\mathrm{day}} \times 5 \frac{\text { days }}{\mathrm{wk}} \times 13$ wks $\times \frac{\$ 15}{\mathrm{hr}}=\$ 35,100$

Approximately $\$ 160,000$

5. Modifications Resulting from Startup

Testing - e.g. Relocating Items, Modifying Instrumentation and Controls, Additional Walls, etc.

Approximately $\$ 300,000$

6. Technical Supply During Demonstration

Two Engineers $\times 8 \mathrm{hrs} /$ day $\times 5 \frac{\text { days }}{\mathrm{wk}} \times 26 \mathrm{wks} \times \$ 40 / \mathrm{hr}=\$ 83,200$

Approximately $\$ 80,000$

7. Documentation of Startup and Demonstration

Assume 1 man-year $2000 \mathrm{hrs} \times \$ 40 / \mathrm{hr}=\$ 80,000$

8. 0\&M During Demonstration .

Two Operators $\times 3$ Shifts $\times 8$ hrs $\times 7$ days $\times 26$ wks $\times \$ 20 / h r=\$ 175,000$

1 Waste Handler $\times 3$ Shifts $\times 8$ hrs $\times 7$ days $\times 26$ wks $\times \$ 15 / h r=\$ 65,500$

1 Health. Physics $\times 12$ hrs $\times 7$ days $\times 26$ wks $\times \$ 15 / h r=\$ 33,000$

1 Maintenance $\times 8$ hrs $\times 5$ days $\times 26$ wks $\times \$ 15 / h r=\$ 15,600$

1 Manager $\times 2$ hrs $\times 5$ days $\times 26$ wks $\times \$ 35 / \mathrm{hr}=$

$\frac{\$ 9,100}{\$ 298,200}$

Approximately

$\$ 300,000$ 